\title{
The gift that keeps on giving: corporate giving and excessive risk-taking
}

\section{Colleen M. Boland ${ }^{1} \cdot$ Corinna Ewelt-Knauer ${ }^{2} \cdot$ Julia Schneider $^{2} \mathbb{D}$}

Accepted: 31 August 2021 / Published online: 24 September 2021

(C) The Author(s) 2021

\begin{abstract}
Corporations have recently started incorporating employees' prosocial preferences into their incentive schemes, including charitable donations (corporate giving). These donations are mainly discussed in conjunction with the external effects of a firm's CSR strategy. However, this experiment examines the effect of donations on internal firm operations. Specifically, we investigate whether the presence and structure of corporate giving influences employees' excessive risk-taking. Such prosocial activities may remediate misaligned incentives often cited as drivers for employees to take excessive risks. Contrary to widespread practice, our experimental evidence suggests that firms could constrain employees' excessive risk-taking by linking existing contributions to project rather than corporate performance, thus providing boundaries around an employee's involvement in CSR initiatives. We identify project-level giving as an unexplored CSR benefit and infer that personal responsibility effectively changes an employee's incentive package. Our findings suggest an inverted U-shape curve of effectiveness.
\end{abstract}

Keywords Incentive contract $\cdot$ Excessive risk-taking $\cdot$ Corporate social responsibility $\cdot$ Corporate giving $\cdot$ Prosocial incentives $\cdot$ Experimental economics

JEL Classification C91 $\cdot$ J30 $\cdot$ M14 $\cdot$ M41 $\cdot$ M52

IRB approval has been granted by the institution at which the experiment was conducted.

Julia Schneider

Julia.Schneider@wirtschaft.uni-giessen.de

Colleen M. Boland

bolandc@uwm.edu

Corinna Ewelt-Knauer

Corinna.Ewelt-Knauer@wirtschaft.uni-giessen.de

1 University of Wisconsin-Milwaukee, 3202 N. Maryland Ave., Milwaukee, WI 53211, USA

2 Justus Liebig University Giessen, Licher Str. 62, 35394 Giessen, Germany 


\section{Introduction}

Properly designed incentive contracts encourage managers to take appropriate levels of risk. However, misaligned incentives can trigger excessive risk-taking behavior, leading to potentially disastrous consequences. For instance, excessive risk-taking behavior is often cited as a root cause of the 2007-2009 global financial crisis (Kirkpatrick 2009). Notably, prior US Federal Reserve Chairman Ben Bernanke observed that during the global financial crisis "compensation practices at some banking organizations have led to misaligned incentives and excessive risk-taking, contributing to bank losses and financial instability" (Federal Reserve Press Release 2009). Through tournaments and other competitive schemes, firms may incite employees at all levels to exhibit excessively risky behavior (Acharya et al. 2016; Backes-Gellner and Pull 2013). In response to the risk-taking concerns, both regulators and firms have put forward demands for restrictive compensation measures (Jokivuolle et al. 2019). However, the regulations and restrictions enacted did not always prove useful in reducing risk, and they sometimes even precipitated unintended consequences. For example, Dittmann et al.'s (2011) analysis uncovers that the firm's value can drop when the restriction forces firms to reject managerial talent or effort. This study examines one non-pecuniary incentive, an existing Corporate Social Responsibility $(\mathrm{CSR})^{1}$ initiative, to rein in excessive risk-taking.

Organization theory and business ethics research note the efficacy of a firm's CSR efforts (e.g., Clarkson 1995; McWilliams and Siegel 2001; Swanson 1995, 1999). Firms develop CSR programs to establish legitimacy and balance stakeholders' expectations, thus honoring economic and social agreements between the firm and its stakeholders and positioning the firm as a socially responsible (or morally based) entity. Valentine and Fleischman (2008) emphasize that regardless of the CSR program utilized, the firm's motivations are, among others, to make its CSR efforts more salient to employees and improve ethical employee behavior. ${ }^{2}$

To date, accounting research addresses where taking additional risks is profitable (e.g., Sprinkle et al. 2008) and examines the drivers of excessive risk-taking behavior, most notably financial incentives (e.g., Brink et al. 2017) or tournament

\footnotetext{
${ }^{1}$ CSR involves discretionary actions that reach beyond traditional profit-making motives (Valentine and Fleischman 2008).

2 Employees often have to choose one out of two opposing alternatives (Chen 2015): they can either continue with an established process or innovate. Similar trade-offs arise in other principal-agent relationships whenever the agent's choice options differ in their risk content, and the agent is (partly) motivated by social concerns. For example, on behalf of their clients, attorneys often have to decide whether to settle (with known reward or punishment) or go to trial (whose outcome is uncertain). Doctors regularly choose between a safe treatment (e.g., a long-established drug regimen) and a risky one (e.g., a new off label use of an approved drug), and blue-collar workers may choose to search for process improvements (risky option) instead of running through the normal process (safe option). How will a firm's prosocial cues influence the decision? Will employees act conservatively because the safe option prevents failure? Or will employees take too much risk, choosing the overly risky alternative in the hope of success? In the spirit of these examples, our setting has no middle ground and taking incremental risk is unprofitable. However, we acknowledge there are many settings that do not require a binary choice. Our results may not generalize to these settings.
} 
competition (e.g., Eriksen and Kvaløy 2017; Schedlinsky et al. 2016). Brink et al. (2017) call for future research on how to reduce excessive risk-taking. Therefore, rather than revisiting compensation systems' effects, this study examines an alternative, non-pecuniary instrument to inhibit employees from taking excessive risks. Specifically, by holding compensation constant, we determine the impact of different corporate giving programs on employees' excessive risk-taking behavior. Employees increasingly expect their firm to promote socially responsible activities, and accordingly, they may search for signals that the firm is meeting their expectations.

Prior research hints at this, showing that firms might benefit from responding to social causes their employees' support (Valentine and Fleischman 2008). Perceptions of the firm are likely to depend on the CSR program's characteristics, including the program's implementation (i.e., corporate or project level); they determine an employee's responsibility in the firm's CSR initiatives (Corbett et al. 2018). Thus, a firm might fine-tune employees' risk-taking behavior by appealing to their social tastes and creating a sustainable risk culture (Lazear 2018). For example, a high proportion of performance-contingent pay attracts and retains a skilled workforce and motivates employees to provide additional effort, albeit at the cost of excessive risk-taking. Aligning incentives to employees' social preferences is worth considering for (based on performance) jobs with employees having a strong loyalty to their firm. In this experimental study, we test whether corporate giving in general and the level of employee empowerment specifically in corporate giving programs can successfully curb employees' excessive risk-taking behavior.

Our experiment first explores whether the presence of corporate giving, a popular CSR activity, influences employees' excessive risk-taking behavior. We assume that the anchor of corporate giving, where charitable giving is grounded in a firm's objectives and tied to overall firm performance (corporate-level giving), mitigates employees' excessive risk-taking behavior. Drawing on social norm activation theory (Bicchieri 2006), we contend that the "tone at the top's" (Collier and Esteban 2007; Schwartz 2013) charitable attitude and prosocial actions are strong enough to radiate throughout the organization, activating a social norm of employee otherregarding behavior. Next, we analyze whether employee empowerment has an incremental impact on risk-taking. In detail, we research whether project outcomes (i.e., when corporate donations relate to the success of an individual employee's specific projects) reduce excessive risk-taking compared to charitable contributions coupled with overall corporate performance but decoupled from the individual employee. In other words, what is the impact of individual employee responsibility (e.g., corporate-level giving vs. project-level giving)? Leveraging accountability theory (Lerner and Tetlock 1999), we expect that employee responsibility reins in excessive risktaking. Finally, we maximize an employee's empowerment and explore whether the person who selects the charity (firm's senior management or employee) has a differential influence on employees' excessive risk-taking behavior.

Contrary to common practice, where corporate charitable giving is tied to overall firm profits, we fail to find any impact of corporate charitable giving on excessive risk-taking behavior. However, when giving is based on project-level performance, we observe a "cautious shift." Project-level based giving appears to mitigate employees' excessive risk-taking behavior. We attribute this result to the introduction of 
self-accountability. Importantly, our results indicate that this effect does not fade over time. Finally, we show that when employees pick the charitable beneficiary, they experience a "risky shift." That is, employees increase their excessive risk-taking behavior. We speculate that employees' personal involvement drives this risky shift since selecting the charity may lead to motivated reasoning (Kunda 1990) and to seeking a bigger payoff for their charity. Employees engaged in motivated reasoning tend to process information consistent with their wishful outcome and overestimate the investment benefits (Slovic et al. 2007; Small 2011). Overall, our experiment points towards an inverted U-shape curve of effectiveness in that both too low and too high levels of employee empowerment in the firm's CSR activities impair the contracting benefit of corporate giving (Balakrishnan et al. 2011) and are thus suboptimal in creating or maintaining firm value. Our results collectively indicate that specific characteristics of a firm's CSR activities can be utilized as a risk governance instrument, reducing the reliance on pay incentives, lowering compensation payouts for the firm.

Additional analyses corroborate the main findings' robustness. Average excessive risk-taking behavior is lowest in the project-level giving condition and higher in any other condition for the subsample of risk-averse and risk-neutral participants. The risk-reduction effect of the project-level giving program also extends to the riskseeking subsample. Further, the main results hold for the subsample of prosociallymotivated participants, i.e., those to whom giving to charity is important. Here again, we document a U-shape relationship between corporate giving and excessive risk-taking behavior. An increase in employee empowerment in corporate philanthropy to a certain level reins in excessive risk-taking decisions, but after that level, excessive risk-taking slopes upward again.

Moreover, while post-experimental responses suggest that participants, on average, associate corporate giving with low- rather than high-risk investment activities, pairwise comparisons highlight the importance of considering the charity recipients. Participants who choose a charity providing food and medical care (e.g., American Red Cross) allocate much less to overly risky investment alternatives than any other charity type. Urgently needed aid and extreme poverty seem to motivate altruism and thus arouse more restrained risk-taking decisions.

Our study contributes to both theory and practice. CSR and employees' empowerment in CSR activities have received much attention from academics and practitioners (Altenburger 2020; Groom 2018; Huang and Watson 2015; Moser and Martin 2012). Particularly corporate giving is a widespread activity that is realized in many forms and implemented at different organizational levels. In 2015, the top 20 most generous Fortune 500 companies granted $\$ 3.5$ billion in cash (Preston 2016) and Microsoft's employee giving program encourages employees to directly connect with local initiatives in various projects involving monetary or time donations (Microsoft 2020). Corporate giving and excessive risk-taking behavior are costly for firms. Currently, most firms make such philanthropic decisions in isolation, tying 
corporate giving to the overall firm profit, ${ }^{3}$ without considering if these donations can effectively be used to rein in employees' excessive risk-taking behavior, an unexplored benefit of CSR.

Second, the recently growing empirical literature using archival data generally documents a negative association between CSR and firm risk (Oikonomou et al. 2012) or a negative relation between CSR and deviations from optimal risk-taking (Harjoto and Laksmana 2018). Our laboratory experiment provides causal evidence documenting this negative association while removing many of the confounding factors present in the field (Hales et al. 2016). ${ }^{4}$ Third, there is literature showing that a firm's CSR practices affect employee behavior. For instance, some studies find that a firm's CSR commitment improves employees' organizational commitment, motivation, or performance (e.g., Balakrishnan et al. 2011; Peterson 2004)—desirable behavioral outcomes. However, there is only little evidence of whether and how a firm's CSR actions can be utilized to mitigate undesirable behavioral outcomes. In this vein, we show how different charitable giving structures affect employees' excessive risk-taking decisions-with such decisions being undesirable from an economic perspective as, by definition, they are detrimental to firm performance.

Examining employees' excessive risk-taking decisions is important for at least two reasons (Sprinkle et al. 2008). First, performance frequently is a function of both effort and risk-taking decisions (Bolton et al. 2015a). For example, investment managers are responsible for selecting projects that vary in risk (capital allocation decisions) and implementing selected projects. Second, a firm's CSR practices may differentially affect employees' effort and risk-taking decisions. A firm's CSR program features that induce high effort may differ from the features that encourage (excessive) risk-taking. Inducing employees to perform unappealing work tasks is fundamentally different from choosing between risky alternatives. Indeed, while prior research points to a positive relationship between a firm's CSR commitment and employees' willingness to provide effort (Charness et al. 2016; for a review, see Gond et al. 2017; Tonin and Vlassopoulos 2015), our results demonstrate the boundaries of increasing the level of employee empowerment. A high level of employee empowerment (i.e., personal involvement in choosing the charity) causes employees to engage in motivated reasoning (Kunda 1990), making them believe in the probability of receiving the highest possible payoffs. ${ }^{5}$ These findings illustrate the economic importance of disentangling performance into its fundamental

\footnotetext{
${ }^{3}$ For further details see https:/givingusa.org/giving-usa-2017-total-charitable-donations-rise-to-newhigh-of-390-05-billion/ (accessed on 21.01.2019).

4 Note that our experimental investment context concentrates on excessive risk-taking ignoring that some risk-taking is desirable or even necessary in practice, as is the case for investment options with a positive net present value. This design choice provides a clear decision rule (any further risk taken is detrimental for all parties involved), thus ensuring a high internal validity.

${ }^{5}$ Likewise, Sprinkle et al.(2008) illustrate that, from an individual wealth maximization standpoint, a tradeoff exists between eliciting effort and encouraging profitable risk-taking decisions. Control and reward systems that motivate organizationally desirable behavior along one primary dimension of performance can simultaneously induce actions detrimental to the firm on another dimension of performance.
} 
determinants, neither neglecting one performance dimension nor confounding the effort and (excessive) risk-taking decisions (Sprinkle et al. 2008).

Finally, we corroborate fieldwork which concludes that firms increasingly emphasize a management control system focused on the communication of values and social influence (Heinicke et al. 2016; Marginson 2009) and document under which circumstances "cultural control" occurs. Our conclusion that personal accountability and controllability (via personal involvement) are the key integrating control mechanisms for firms engaging in corporate giving extends the growing literature on cultural control (Heinicke et al. 2016; Kennedy and Widener 2019). We show that too low or high controllability impacts excessive risk-taking behavior. Our results may help firms design an appropriate social value incentive system to maintain or alter excessive risk-taking behavior patterns: too much freedom (e.g., choosing the charity) may be counter-effective.

The paper proceeds as follows: Sect. 2 reviews the literature and provides background information on charitable giving and excessive risk-taking. Section 3 develops our hypotheses. Section 4 outlines the experimental design. Section 5 presents the results, and Sect. 6 discusses and summarizes the results.

\section{Theory and related literature}

\subsection{Excessive risk-taking}

Employees' excessive risk-taking, defined as the risk associated with business decisions exceeding levels in firm owners' interests (Brink et al. 2017; Eriksen and Kvaløy 2017), can jeopardize firm sustainability. Exchanging a lower expected value for a greater variance puts a strain on the firm's risk-bearing ability. Although there is always the chance of a big payoff, excessive risk-taking behavior also has a high potential for consequential loss and, on average, reduces wealth (speculative dealings with an expected value $<1$; Lefebvre and Vieider 2013). Not only does excessive risk-taking run counter to a for-profit firm's value-maximizing objectives, but it may also harm society at large. In particular, financial sector professionals have been accused of taking excessive risks on behalf of others (Andersson et al. 2016; Cohn et al. 2017). Tournaments, stock option plans, and other asymmetric rewards have been blamed for stimulating excessive risk-taking beyond the banking sector (Eriksen and Kvaløy 2017; Sanders and Hambrick 2007). Due to relatively high amounts of contingent pay (i.e., structural differences in their payoff functions), equity investors often have incentives to take excessive risks to increase their profits at the expense of debt holders and other stakeholders (e.g., through overinvestment). While these excessive risk-taking incentives have received extensive attention in regulatory reforms for executive compensation, ${ }^{6}$ they do not reflect the widespread

\footnotetext{
${ }^{6}$ Such regulations are often predicated on the belief that decreasing the contingent portion of these monetary incentives (i.e., pay linked to earnings per share indicators) will reduce potential agency costs (Brink et al. 2017). In this terminology, our study explores a potential agency (i.e., contracting) benefit (Balakrishnan et al. 2011), that is a CSR instrument to diminish excessive risk-taking behavior.
} 
use of non-executive risk-taking incentives in practice (Murphy 2013). More than half of U.S. corporations employ some tournament schemes, where all types of employees - ranging from production-line workers to salespersons to mutual fund managers-compete for promotions, bonuses, or prizes (e.g., "employee of the year" awards) (Backes-Gellner and Pull 2013). A malfunctioning reward system may create unsustainable norms, self-regarding beliefs, and maladaptive paradigms that encourage employees at all levels to make "high-variance" rather than "good" investments (Cohn et al. 2017; Conyon et al. 2011). This study incorporates other stakeholders into employees' daily investment decisions and links risk-taking and responsibility for others to inhibit excessive employee risk-taking.

\section{2 (Excessive) Risk-taking on behalf of others}

An employee's risk-taking choices affect others (Trautmann and Vieider 2012), including the firm's stakeholders (e.g., firm owners, customers, and employees). For socially responsible firms, they also extend to the beneficiaries of that responsibility. In our setting, because the firm has corporate giving programs, the charity's recipients are also firm stakeholders, and therefore an employee's risk-taking decisions have implications for the charity.

A small but growing stream of research investigates how people take risks with “other" people's money. These studies combine risk and responsibility to examine risk-taking behavior when decision-makers are accountable to another individual (e.g., Andersson et al. 2016; Pahlke et al. 2015) or group (e.g., Bolton et al. 2015b). Consistent with the saying "better safe than sorry," the studies corroborate the notion that perceptions of social responsibility, or accountability, are associated with caution (Bolton et al. 2015b). Feeling responsible for other people's money tends to motivate more careful investment strategies (Pollmann et al. 2014; Weigold and Schlenker 1991). A decision maker's responsibility or care for other people's fortune (Charness and Jackson 2009) appears to align risk behavior more closely to the beneficiaries' interests (Lefebvre and Vieider 2013).

We build on this reasoning when researching whether excessive risk-taking can be reduced by linking an investment decision to a charity. A charity's known financial needs heighten employees' altruism preferences, feelings of social responsibility, and inequality aversion (Andreoni and Miller 2002; Fehr and Schmidt 1999). We argue that such social or other-regarding preferences (Cooper and Kagel 2016) are likely to offset a decision maker's propensity for excessive risk-taking. Employees should have an incentive to protect and bolster their firm's, their own, and a charity's financial health: excessive risk-taking behavior is contrary to the idea of firm sustainability.

\subsection{Beyond the principal-agent contract: an organizational setting with social norms}

Grounded in economics, agency theory models the firm as a nexus of contracts between principals who delegate services and agents who perform them (Jensen and 
Meckling 1976). As employees (i.e., agents) do not bear the full wealth effects of their decisions, employees' risk orientation may not be perfectly aligned with that of the firm owners (i.e., principals). For example, overinflated equity compensation practices and a one-sided emphasis on yield may cause employees to incur unsustainably high debt levels (i.e., creating a malfunctioning incentive contract), resulting in principal-agent conflicts (Jensen and Meckling 1976; Till and Yount 2019). Firms minimize these conflicts through corporate policy and risk governance. Risk governance aims to establish supervisory and incentive mechanisms that align employees' risk orientation with firm owners' interests. Identifying those motivators is central to addressing principal-agent conflicts and strengthening a sustainable firm risk culture.

The traditional "homo economicus" model which underlies the agency theorybased research in this field, relies on pecuniary incentive components. In its simplest form, agents are assumed to be purely self-interested and have private utility increasing in earnings (Rebitzer and Taylor 2011). They do not attach the same value to more socially sophisticated elements, such as social norms or desires for altruism and charitable activities unless these elements will somehow affect an employee's wealth.

Recent research is challenging the notion that employees are narrowly self-interested (Till and Yount 2019); instead, employees care for the proceeds generated for needy others, in addition to their own (Berg and Gigerenzer 2010). By sticking to social norms and displaying generally respected modes of conduct, people view themselves favorably: they are altruistic, generous, and helpful (Tonin and Vlassopoulos 2013). Individuals derive private value from the act of helping (Imas 2014; Rotemberg 2006); that is, they experience an emotional reward, the feeling of a "warm glow." Firms can leverage individuals' taste for altruism in several ways. For example, they can connect a work task to a meaningful outcome (Ariely et al. 2008) or emphasize the impact of tasks (Grant 2008) through corporate giving.

To investigate how firms may capitalize on employees' social or other-regarding preferences (Cooper and Kagel 2016), especially their taste for altruism, Sitkin and Pablo (1992) identify three elements explaining employees' risk behavior within a firm: individual characteristics, problem-related characteristics, and organizational characteristics. Their risk framework refines traditional principal-agent theory which is generally silent concerning the potential for social norms of other-regarding behavior to emerge in employees. For social norms to matter to an employee's utility, they have to be efficacious - and to be efficacious, they must be salient. Essentially, situational cues lead an employee to interpret the decision context as one to which a given norm applies, pay attention to the norm, and conform to it (Bicchieri 2006, 2008). Positive motivational effects can be obtained by linking what employees value - or want to avoid - to measured outcomes (Nelson 2012). Beyond cash, firms use social incentives and integrate them into employees' total reward and compensation package to guide their risk-taking (Nelson 2012; Sprinkle and Maines 2010).

Whereas some CSR incentive programs personally involve employees, making the individual employee accountable, other programs and program features more indirectly influence individual responses to work and dealing with risk (e.g., 
employees' beliefs or perceptions concerning a firm's involvement in CSR). As such, the firm's incentive structure (economic incentives vs. economic and social incentives) communicates its objectives and sets its core values (profit-orientated goals vs. profit-orientated and social goals).

While "the role of "value systems" as a mechanism of management control" (Marginson 2009, 7) and the need for "an accountability-oriented control system" (Merchant and Otley 2006, 792) are generally acknowledged, the role of CSR and an employee's personal accountability and empowerment in CSR play in the system is still open to debate. Burbano (2016) documents that employees respond to a socially responsible message about an employment situation with lower wage claims. Firms engaged in prosocial programs are viewed as more likable and more trustworthy (Burbano 2016; Fehrler and Przepiorka 2016). Employees reciprocate such prosocial signals with desirable, norm-compliant behavior (Kajackaite and Sliwka 2017). Hence, the mere presence of corporate giving changes the way decision-makers mentally frame the situation, causing them to perceive the firm as one that "does good." As such, CSR actions likely foster the relational contract between employees and the firm (Valentine and Fleischman 2008).

Similarly, Durden $(2008,671)$ notes that "informal [or relational] control [is a] key aspect in developing a management control system that incorporates social responsibility considerations" and thus is central to risky organizational decisionmaking. Management control systems shape employees' practices and support strategy. If used appropriately, these systems push employees toward socially sustainable business decisions (Gond et al. 2012). Based on these findings, we expect that a firm's CSR activities, such as charitable contributions, will spill over to internal firm dealings (e.g., an employee's investment decisions), resulting in less excessive risk-taking behavior and a higher firm value.

\section{Hypotheses development}

\subsection{Effect of charitable giving tied to overall firm profits on excessive risk-taking}

Senior management's corporate strategy and mission statements incorporate CSR initiatives. Contributions (i.e., corporate giving programs) are often based on firmwide performance. This message from the top conveys a signal to employees that the firm is socially responsible ("pro-CSR tone") and sets a norm as to what is appropriate (Church et al. 2019). A firm that supports and engages in a prosocial activity tends to refrain from irresponsible, unsound, potentially harmful business decisions (e.g., excessive risk-taking). Rather, responsible and sustainable decision-making

\footnotetext{
7 In management control terminology, value systems are "the explicit set of organizational definitions that senior managers communicate formally and reinforce systematically to provide basic values, purpose, and direction for the organization" (Simons 1995, 34). Value systems serve to inspire, guide, and motivate behavior through the use of broad value-laden concepts (Simons 2000; Mundy 2010) allowing employees to engage in responsive actions (Heinicke et al. 2016).
} 
is preferred (Benabou and Tirole 2010; Bowles and Polanía-Reyes 2012; Joshi and Li 2016). Social norm activation theory (Bicchieri 2006) posits that an individual's perceptions of expected behavior trigger concerns about complying with the norm (i.e., the expected behavior). Costly prosocial activities like corporate giving are likely to be a salient aspect of the employment setting, thus activating a norm of employee other-regarding behavior (Douthit et al. 2019). Because employees derive utility, or a "warm glow" feeling (Andreoni 1990), from helping others (i.e., the firm and/or charity), we assert that this social norm-based influence from the top will restrain employees from taking excessive risk. Employees will reciprocate the firm's socially responsible message with norm-compliant behavior (Kajackaite and Sliwka 2017; Noreen 1988).

Our conceptual mediation model (Fig. 1) illustrates how the presence of corporate-level giving affects employees' perceptions of the firm's prosocial business practices, a signal of senior management's expectations of employees' risk-taking behavior. Corporate giving communicates to employees that excessive risk-taking on behalf of the firm is unwelcome because excessive risk-taking behavior can endanger the firm's financial viability and its prosocial direction. We expect employees' decision problems to be framed in terms of other-regarding and society-serving objectives when a portion of overall firm earnings is donated to charity: overly risky behavior would not comply with the firm's norm of other-regarding behavior. All else equal, the presence of corporate-level giving should lead employees to mentally frame the firm as one that "does good" and also induces employees to employ "healthy" risk levels that serve the firm's prosocial practices.

However, due to their indirect and broad nature, corporate-level donations are not directly tied to individual employees' daily work, and thus an employee's contribution is not transparent. Firm-based performance measures aggregate the relationship between specific activities (e.g., risk-taking decisions) and their consequences. Therefore, such obscure measures are inadequate for understanding the impacts of an employee's excessive risk-taking decisions. Rather, corporate-level giving may be best imagined as a portfolio of projects-some of which have positive impacts, others with negative impacts and still others with small or no net prosocial impacts (Corbett et al. 2018). Consequently, donations at the corporate level are remote from the employee and bring about controllability problems (Merchant and van der Stede

\footnotetext{
8 An alternative explanation is that managers may engage in philanthropic impression management and opportunistic window dressing. Especially firms with legitimacy concerns are likely to engage in such activities to conform to expected social behavior and stakeholder demands and, in turn, to obtain, protect or restore their social license to operate (Aguilera et al. 2007; Chen et al. 2008; Du and Vieira 2012; Filatotchev and Nakajima 2014). For example, Gond et al.. (2012) observe that many firms hide behind sustainability rhetoric in their mission statements to reconstruct an eroded legitimacy. Taking a behavioral perspective, Cassar and Meier (2017) show that the functioning of prosocial incentives depends on how employees perceive the firm's intentions for using those incentives and not just the direct effect of the incentives for the good cause. If prosocial incentives are seen as being used strategically, i.e., the firm's perceived intention is to benefit from the prosocial incentives, employees view the firm as less prosocial and react unfavorably to the incentives. Corporate-level giving, if used strategically, can backfire, i.e., create a negative signaling value of the firm's type that possibly outweighs its intended (excessive riskreduction) effect.
} 
2017). These donations precipitate a "diffusion of responsibility" (Charness and Jackson 2009; Latané and Nida 1981) since only a few top senior managers in the firm, i.e., those who can make strategic decisions, significantly influence them. They say little about the performance and excessive risk-taking decisions of individuals lower in the firm's hierarchy. As a result, because corporate-level giving is outside an employee's purview and control (and sometimes awareness), it may lose any individual employee's value or incentive effect.

Since there has been little prior research as to whether corporate-level giving is salient enough to prime or activate a norm of other-regarding behavior, our first hypothesis is as follows, stated in the null:

H1 Relative to no giving at the corporate level, the norm activation effect of corporate-level giving is not associated with an employee's excessive risk-taking behavior.

\subsection{Effect of charitable giving tied to project-level performance on excessive risk-taking}

In deriving our second hypothesis, we add to senior management's "pro-CSR tone" (i.e., giving to charity) with perceived accountability. Pirson and Turnbull (2016) argue that decentralized corporate governance structures handle CSR complexity better than centralized structures. Church et al. (2019) observe that large corporations often decentralize CSR decision-making to facilitate CSR implementation and promote morale. In these corporations, after senior management has determined the overall CSR strategy, middle managers' and rank-and-file-employees' investment decisions are linked to CSR (e.g., using project-level performance as the measurement basis for decision-making). In this case, project-level performance directly determines the amount of charitable giving which the individual employees achieve-unlike a corporate giving program established at the top of the firm that socially influences or primes the individual employees lower in the hierarchy with its prosocial signals radiating to them $(\mathrm{H} 1)$.

In this setting, the amount the firm donates to charity is tied to the success of an individual employee's specific projects (project-level giving) rather than overall firm success. The project setting is employee-centered and reduces the "diffusion of responsibility" inherent in corporate-level giving programs focusing on senior management's CSR policy. Employees move from being influenced (H1) to being personally responsible $(\mathrm{H} 2)$ as they perceive control over and feel personally accountable for the project outcome. Following accountability theory (Lerner and Tetlock 1999), the perceived importance or salience of excessive risk-taking consequences will be greater than when corporate-level decision-making conceals an individual contribution (Merchant and van der Stede 2017). Linking project-level performance to charitable giving makes harming the welfare of "others," i.e., the potential loss to the charity, more transparent to employees and has a greater effect than when giving is based on overall corporate performance. Employees "should be able to see more clearly how the design 


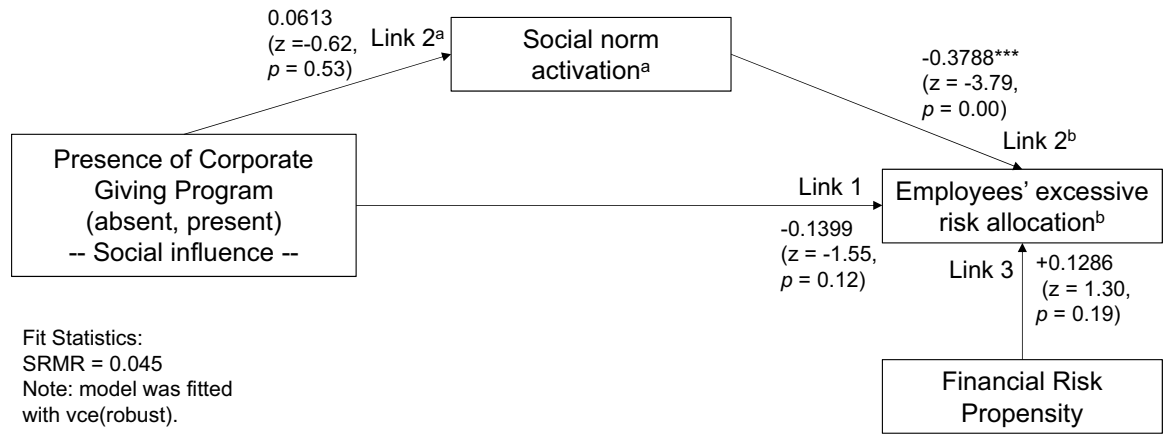

Fig. 1 Theoretical mediation model for H1. *, **, *** significant at the 0.10, 0.05, and 0.01 levels, respectively. It shows the standardized path coefficients for the model that uses the presence of the corpo-

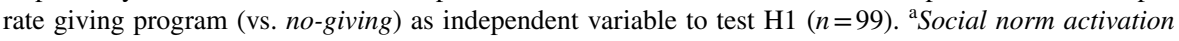
represents answers provided on an eleven-point-Likert scale $(1=$ very untrue of me; $11=$ very true of me) for the following item: Senior management's stated goals affected my investment decisions in the way that I allocated more points to investment alternative A. ' Employees' excessive risk allocation is the mean excessive risk allocation over all ten rounds, comparing the no-giving with the corporate-level giving, project-level giving and charity selection conditions

of social projects affects specific social and economic outcomes for the [charitable recipients] and how they benefit the organization along the same outcome dimensions" (Salazar et al. 2012, 176).

Employees thoroughly evaluate the investment problem and the available options to choose the option most clearly defensible due to feelings of controllability and personal accountability (Simonson and Nye 1992). Decision-makers attach weight to the loss-probability of excessive risk allocations and view such an investment as overly loss-prone. Employees dislike feeling accountable for relatively probable negative outcomes, and personal accountability deters harming others (Hall et al. 2007). For employees in charge of the investment project, excessive risk-avoiding behavior becomes relatively more important. They understand their responsibility for a poor outcome to the firm and, by extension, to the charity and anticipate guilt, regret, or dissatisfaction (Pham 2007). Ceteris paribus, as shown in Fig. 2, we expect that the positive (i.e., excessive riskdiminishing) effect between the corporate giving program and excessive risktaking is mediated through the impact of employees' perceived accountability for charitable contributions.

To summarize, because the investment outcome is within their scope of responsibility, employees perceive personal accountability to decide in the firm's and the charity's best interests, i.e., engage in less overly risky behaviors. Thus, we expect the project-level giving contract to encourage a more conservative approach (i.e., a cautious shift) and align risk-taking decisions with corporate economic goals. Formally, our second hypothesis is in the alternate form:

H2 Relative to corporate-level giving, the personal responsibility effect of projectlevel giving decreases employees' excessive risk-taking behavior. 


\subsection{Employee involvement in charity selection and its impact on excessive risk-taking}

Next, we explore the effect of employees' participation in selecting the charity as the project's payoff beneficiary. The employee's empowerment shifts from personal responsibility $(\mathrm{H} 2)$ to personal involvement $(\mathrm{H} 3)$. Since the employee chooses the charity, the firm's prosocial mission likely matches employees' individual needs and beliefs (Koppel and Regner 2014; Smith 2016). Employee involvement in charity selection provides a better mission match with the charity type and purpose, leading to higher emotional proximity. Recently, Resh et al. (2018) propose that "mission match" and identification with the organization's mission are more significant than broad-based, other-regarding, or societal orientations which persistently increase employees' prosocial effort. But theory and research leave it open whether this finding can also be generalized to excessive risk-taking behavior.

If project specificity, personal connection, and emotional proximity were the mechanisms for excessive risk-taking mitigation, we would expect charity selection to have the lowest level of excessive risk allocations. The idea is that employees sympathize more strongly with the charity and its objectives (Akerlof and Kranton 2005; Small and Simonsohn 2008) when selecting the charitable cause than when the firm's senior management holistically selects on behalf of the firm. Given this sympathy, employees may be more motivated to decide in the best interests of their chosen charity (Charness and Gneezy 2008; Montinari and Rancan 2018). We expect employees to make more careful and conservative decisions for a socially close charity to provide the highest expected payout.

However, active engagement and empowerment in a firm's CSR issues could lead to irresponsible decision-making due to motivated reasoning (Kunda 1990). Motivated reasoning means that individuals tend to access and interpret available information consistent with their preferences and expectations, especially when they have a strong emotional stake in the decision. Personal involvement in the charity selection process creates an emotional stake that may make an employee engage in motivated reasoning - based on what the employee wants to believe. Charity selection may shift employee motivation from being "an appropriate investment allocation" (accuracy goal) to "reaching a desired investment outcome" (directional goal) for the selected charity. This new focus causes employees to emphasize the favorable project outcome and ignore the possibility of a loss (Hales 2007). Such an emotional or irrational response may arise since customized charitable contributions stem from the heart (Small 2011), and affective responses to vivid objects tend to be more extreme than reason-based assessments (Pham 2007).

Further research highlights that pleasant emotions such as enthusiasm trigger generally optimistic risk assessments (Druckman and McDermott 2008 and the references cited here). People judge risk by what they think and how they feel about it (Slovic and Peters 2006). Given that employees feel favorable towards the selected charity, they are more likely to judge the risks (benefits) of a risky option as low (high) (affect heuristic; Slovic et al. 2007). Although the odds of a large gain are extremely low, a risky decision could lead to a large gain and enhance the charity's welfare more than the less risky option. As employees become more personally 


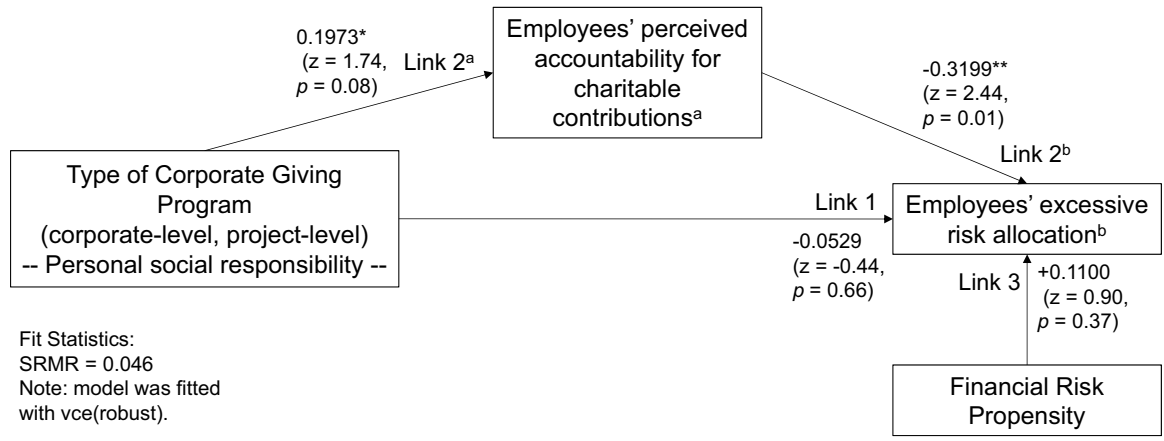

Fig. 2 Theoretical mediation model for H2. *, **, *** significant at the $0.10,0.05$, and 0.01 levels, respectively. Figure 2 shows the standardized path coefficients for the model that uses the type of the corporate giving program (corporate-level vs. project-level) as independent variable to test $\mathrm{H} 2(n=70)$. 'Employees' perceived accountability for charitable contributions, a two-item principal factor (eigenvalue $=1.33$, explained variance $=1.16$ ), is derived by using factor analysis. It represents answers provided on an eleven-point-Likert scale ( $1=$ very untrue of me; $11=$ very true of me) for the following items: (i) Senior management's stated goals affected my investment decisions in the way that I allocated more points to investment alternative A, and (ii) The fact that a given percentage of my investment decisions' payoff is donated to charity, influenced my investment decisions in the way that I allocated more points to investment alternative A. ${ }^{\mathrm{b}}$ Employees' excessive risk allocation is the mean excessive risk allocation over all ten rounds, comparing the corporate-level giving condition with the project-level giving and charity selection conditions

involved in CSR decision-making, they will likely experience unpleasant emotions related to the prospect of not taking the risky option. Specifically, they will anticipate regretting having waived the favorable investment outcome. Employees' attention moves from the security potential of investments (i.e., where they focus on the worst possible outcomes and weigh them heavily in decision-making) to aspiration (Luft and Shields 2009; March and Shapira 1992). Their impact on their chosen charity in mind may drive employees to emphasize the best possible outcomes and weigh these outcomes more heavily in risky decision-making. Consequently, they are willing to undertake high-risk, high-return projects.

Since theory and extant literature are relatively unambiguous as to which of the competing forces prevails, we posit the following hypothesis:

H3 Personal involvement in designating the recipient charity increases employees' excessive risk-taking when giving is tied to project-level performance.

\section{Method}

\subsection{Experiment design, manipulated variables, and task description}

To test our hypotheses, we conduct a $1 \times 4 \times 10$ mixed-design laboratory experiment. We vary between subjects, the presence and type of the corporate giving program among four treatment conditions: no giving, corporate-level giving, project-level 
giving, and charity selection. ${ }^{9}$ To rule out one-time effects and detect end-game strategies (Schedlinsky et al. 2018), we conduct ten independent rounds with the same performance-based compensation scheme across all rounds and conditions.

Participants make ten identical investment decisions that influence either overall firm earnings (no giving and corporate-level giving) or individual project performance (project-level giving and charity selection). In our baseline condition, no giving, overall firm profit is distributed to the shareholders, an anonymous group of investment decision beneficiaries. Before making investment decisions, participants assigned to the corporate-level giving condition learn that $10 \%{ }^{10}$ of the overall firm profit donations, including their investment decisions' payoff, are donated to senior management's chosen charity, the American Red Cross. Participants assigned to the project-level giving (charity selection) condition learn that $10 \%$ of their investment project's payoff is directly, i.e., independent of overall firm performance, sent to senior management's identified charity, the American Red Cross (the individual participant's chosen charity). The amount that goes to the charity is calculated similarly across the giving treatments. Any distinction between these treatments is due to employee empowerment and, because prosocial norms are highly context-sensitive (Bicchieri 2008), the framing of the charitable contribution. ${ }^{11}$ Table 1, Panel A, depicts the experiment material's exact wording of the firm's senior management's stated strategic goals.

We use z-Tree software to conduct our experimental risk-taking task that involves the investment decisions (Fischbacher 2007). Based on an adapted version of Gneezy and Potters' (1997) risky lottery, participants receive an endowment of 100 points to allocate between two investment options. These investment options are labeled investment alternatives $\mathrm{A}$ and $\mathrm{B}$ to avoid framing language effects. ${ }^{12}$ As long as the 100 points remain fully invested, the allocation of the 100-point endowment

\footnotetext{
9 We list all the variables we have manipulated and measured for testing our hypotheses within the supplemental data (see Table 1, Panel B). This list also specifies which are the dependent, independent, and covariate variables.

10 While10 percent may be very high and might not reflect the average business context, corporate giving varies from sector to sector and from firm to firm, and is highly responsive to changes in corporate pre-tax dollars as well as GDP. The report, Giving in Numbers: 2018 Edition, found that the top quartile of firms collectively donated at least $\$ 55.3$ million, or 1.8 percent of their pre-tax profit, up from $\$ 53$ million and 1.7 percent in 2016 with the health care sector firms donating 7.8 (6.0) percent in 2017 (2016). Moreover, experiments test directional predictions (here, the effect of corporate giving on excessive risk-taking), rather than point estimates. Consequently, the fixed percentage value may influence the strength, rather than the direction, of the effect.

11 We thank an anonymous reviewer for this interpretation. "Context-sensitive" or "context-dependent" means that different social norms will be activated, or appear appropriate, depending on how a situation is understood. Even a small change of the decision frame context may elicit different, even opposite, preferences (Bicchieri 2006).

12 Alternative A has no risk but also no (zero) return. It guarantees a safe repayment of the amount invested. By contrast, alternative B has a dyadic payoff structure, resulting in a win of 2.5 times the investment or a loss of the entire allocated amount as emphasized with a screen that popped up after each investment decision with a "WIN" or "LOSE" message. The investment alternatives A and B are explained in more detail in the supplemental data. Figure 1 in the supplemental data illustrates the payoff structure resulting from the two alternatives and Table 1 (also enclosed in the supplemental data) depicts the expected value calculation of the alternatives.
} 
is at the participant's discretion. ${ }^{13}$ The amount invested in alternative B, our primary dependent variable, is our proxy for excessive risk-taking. Economically, each marginal increment invested in investment $\mathrm{B}$ means accepting excessive risk and, due to its inferior expected value (ratio of $0.8 \overline{3}$ to 1 ), is detrimental to the firm.

The widely used Gneezy and Potters' (1997) risk elicitation method supports loss aversion in financial decisions of both students and professionals (see Charness et al. 2013 for a review). We chose the Gneezy and Potters' (1997) risky lottery because it requires participants to choose between no risk (and no chance of increasing their money through investment) and excessive risk (a chance of increasing their money through investment, but at a lower expected value). To obtain a clear decision rule, we concentrate on excessive risk-taking as the only risk option (Brink et al. 2017; Schedlinsky et al. 2016). Taking the additional risk has harmful effects on the employee, the shareholders, and the charity. If we had broadened our focus and added a third positive net present value investment alternative (i.e., with an expected value above one) covering (profitable) risk, taking on more risk would have been desirable depending on the participant's risk-taking propensity. Our experimental approach was to construct a situation where the optimal strategy was to take no risk, regardless of the individual participant's risk-taking propensity (Eriksen and Kvaløy 2017) and then vary the charitable giving frame. ${ }^{14}$ Although the task does not distinguish between risk-neutral and risk-averse behavior, controlling for attitude toward risk, the amount allotted to alternative B provides a fairly good metric for capturing treatment effects in excessive risk-taking behavior (Charness et al. 2013). Individuals choose among risky prospects by balancing the value of the possible consequences, comparing all available options and possible outcomes, and incorporating factors of the business environment (Mellers 2000; Simonson 1989). In our simplified decision-making environment, by construction, the less employees invest in alternative B, the less they destroy firm value and the more they act in their firm's best interests. The investment outcome of the most recent investment decision (total investment payoff) and the allocation to the participants and to charity, respectively, are reported at the end of each round (of the experiment).

\subsection{Participants}

The participants were recruited from a large Midwestern US university. In total, 129 students took part in the experiment. Students who answered at least one out of three manipulation check (MC) questions incorrectly (30) were excluded from

\footnotetext{
13 A calculation formula and an understanding check expressly indicate that an allocation of zero to either alternative is valid. Across all rounds 12.22 percent of the participants made no allocation (i.e., invested zero points) to the risky option (alternative B).

14 A post-experimental question asks about the riskiness of investment alternative B (eleven-point-Likert scale: 1 - not at all risky; 11 - extremely risky). Participants' mean responses of 8.51 are significantly above the scale's midpoint $(t=13.03 ; p<0.001)$, with no significant differences between conditions $(F=0.48, p=0.6950)$.
} 
Table 1 Extracts from the experimental materials and variables

Panel A: experimental conditions

No giving

Corporate-level giving

Project-level giving

Charity selection "the firm's senior management's stated goal is to make profits (i.e., generate a return on investment)."

"financial gain is the only criterion used to determine the choices made by the firm's senior management."

“the firm's senior management's stated goals are to make profits (i.e., generate a return on investment) and to be charitable (i.e., tying overall firm profit to charitable giving)."

"besides financial gain, charitable criteria are used to determine the choices made by the firm's senior management."

"the firm's senior management's stated goals are to make profits (i.e., generate a return on investment) and to be charitable (i.e., tying your specific investment project profits to charitable giving)."

"besides financial gain, charitable criteria are used to determine the choices made by the firm's senior management."

“the firm's senior management's stated goals are to make profits (i.e., generate a return on investment) and to be charitable (i.e., tying your specific investment project profits to charitable giving)."

"besides financial gain, charitable criteria are used to determine the choices made by the firm's senior management."
Panel B: list of variables

Dependent variable

Excessive Risk-taking

Independent variables

Corporate Giving Program

Round

Covariates

Financial Risk Propensity Factor

Altruism Factor
Excessive risk allocation as the number of points allocated to investment alternative B.

The presence and type of the corporate giving program. This between-subjects variable is manipulated at four levels: no giving, corporatelevel giving, project-level giving and charity selection.

A within-subjects factor. In total, apart from the two trial rounds, ten rounds of the experiment are conducted.

The measure for participants' risk propensity in the financial risk decision domain. This principal factor is derived through factor analysis using six items placed in the pre-experimental questionnaire (see Table 3, Panel A). Financial Risk Propensity, a persistent but not stable trait, is the reported level of an individual's financial risk-taking tendency.

The measure for participants' prosocial disposition. This principal factor is derived through factor analysis using six items placed in the post-experimental questionnaire (see Table 3, Panel B).

Panel A shows the experimental instruction's precise wording of our manipulated variable, i.e., the presence and type of the corporate giving program. Differences between conditions are highlighted. Panel B describes the manipulated and measured variables of our RM-ANCOVA (see Table 4, Panel A) 
the statistical analysis. ${ }^{15}$ The resulting population consisted of 99 participants (MC sample), 48 females $(48.48 \%)$ and 51 males $(51.52 \%) .{ }^{16}$ Their mean (median) age was 22.45 (21) years, with $90 \%$ between 19 and 27 . Most participants reported their major as accounting (44.44\%), finance $(27.27 \%)$, or marketing $(18.18 \%)$, and they were primarily enrolled in undergraduate-level courses $(84.85 \%)$; the remaining ones were graduate students. Nearly all participants $(95 \%)$ had attended at least one college-level math class. There are no significant differences across our four conditions in terms of gender, age, lab experience, current year of study, current grade status, current overall grade, and attendance of business ethics, finance, and math classes (all $p>0.10){ }^{17}$ Our experiment considers students a representative population since work experience or specialized knowledge is not needed to test our proposed causal relationship between charitable giving and excessive risk-taking. Experiments on social preferences conducted with students typically set the lower bound for prosocial behavior (Belot et al. 2015; Cooper and Kagel 2016), especially when economics students participate in experiments (Cappelen et al. 2015).

\subsection{Experimental procedures}

Upon arrival, the participants were randomly assigned to one of the four conditions. The participants first read instructions that provided general information about the experiment, outlined the session's procedures, and then answered questions designed to measure their risk propensity from the Domain-Specific Risk-Taking (DOSPERT) scale (Blais and Weber 2006). We selected twelve questions covering decision situations in the financial and social risk domain. The question sheet differentiates between the main risk propensity scale $(1=$ extremely unlikely; $11=$ extremely likely) and a risk perception subscale ( $1=$ not at all risky; $11=$ extremely risky). A high (low) risk propensity (risk perception) score indicates a high probability of being risk-seeking in domain-specific decision situations. ${ }^{18}$ While we collected risk propensity data at the outset of the experiment, the four-item risk perception

\footnotetext{
15 The three MC questions were (i) What is your share in the payoff of your investment decisions? (MC 1: Personal share), (ii) Who chose the beneficiary charity of your investment decisions? (MC 2: Method of charity selection) and (iii) To what is charitable giving primarily or directly linked? (MC 3: Charitable giving link). 122 out of 129 (94.57 percent) answered MC 1 correctly. MC 2 and MC 3 had only been part of the giving treatments and 91, respectively 79 students out of 99 (91.92 respectively 79.80 percent) answered these questions correctly. We can speculate why this many students failed to answer all MC questions correctly. Since the initial comprehension quiz was quite detailed, and the instrument was long, we conjecture that students failed to answer all MC questions correctly due to fatigue. The instrument was long.

16 As outlined later, the initial comprehension quiz indicated that all participants had entirely understood the experimental instructions. For comparison, while we report the results based primarily on the smaller sample $(n=99)$, we reran all the analyses, including the 30 participants who failed the MC. Importantly, the results with the full sample of 129 participants are inferentially identical.

17 Unless stated otherwise, all $p$-values are reported on a two-tailed basis.

18 There is considerable variance in the estimation of risk: the same set of circumstances is evaluated differently among individuals. To ensure that organizational characteristics, i.e., the presence of corporate-level giving, rather than the individual risk profile are driving our results, we measure both individual risk propensity and risk perception and integrate the former as a covariate into our analysis.
} 
scores were gathered after the investment task had been completed. Thus, we can determine if our framed charitable giving manipulation was strong enough to alter the participants' risk perceptions relative to their initial risk propensity (Blais and Weber 2006; Sitkin and Pablo 1992). Moreover, eliciting risk preferences ex ante allows for an undistorted measure of individual risk propensity (Brink et al. 2017; Schedlinsky et al. 2016). ${ }^{19}$

Next, the participants read the second set of experimental instructions and completed a comprehension quiz on the experimental instructions. Participants were required to answer all understanding check questions correctly before the session continued. ${ }^{20}$ Participants in the giving treatments reviewed fact sheets about the American Red Cross (corporate- and project-level giving) and the other charities (charity selection). Participants in the charity selection treatment-group (charity selection) selected their charity. ${ }^{21}$

After two practice rounds and ten rounds of the investment task, participants completed a post-experimental questionnaire. In addition to process-related data and the DOSPERT scale mentioned above, the post-experimental questionnaire covers other personality-related influences. Specifically, we control for participants' prosocial disposition using a reduced version of the self-reported altruism scale (Rushton et al. 1981) and select suitable dimensions from the Revised NEO Personality Inventory (Costa and McCrae 1992). Finally, the post-experimental questionnaire includes MCs and demographics. Because all the data was recorded without personal identifiers, our procedures guaranteed participant anonymity. Figure 2 of the supplemental data illustrates the experiment's steps in chronological order.

\footnotetext{
${ }^{19}$ It is common in accounting experiments to measure participants' risk preferences upfront (e.g., Brink et al. 2017; Kreilkamp et al. 2020). We acknowledge that participants could have connected the measurement of their personality with the task in the experiment. However, since the risk propensity elicitation instrument was constant across treatments, it does not take away from the observed differences.

${ }^{20}$ A sample question was "How many investment alternatives are you given in each round? Please indicate the number of investment alternatives given." On average, it took the participants $12.75 \mathrm{~s}$ for a true/ false-statement, $17.25 \mathrm{~s}$ to specify the correct input for an open question with free text responses, and $37.25 \mathrm{~s}$ for a single-choice question respectively.

${ }^{21}$ There are tradeoffs as to the number of charities used in the experiment. A high number of total charities makes it more likely for a participant to find a charity that he prefers to support. However, too high a number may cause choice overload, meaning that the participants are overwhelmed by the choices in the experiment. Similar to topically related experiments (e.g., Brown et al. 2017), participants must select one charity from a menu of ten charities which included brief descriptions of the charities' activities. We do not believe choice overload is a serious issue here, as the charities and their principal work were concisely listed on one screen. A survey item placed after the participant has selected the charity reveals a significant mission match with Likert-scale responses significantly greater than the scale midpoint $(t=15.84, p<0.001)$. It took the average participant slightly more than one minute to choose the charity and only few participants took more than two minutes for making their decisions.
} 


\subsection{Monetary compensation and prosocial incentives}

During the experiment, all earnings and profits are measured in points, our experimental currency. After converting points to US dollars, each participant earned their variable payment in addition to a $\$ 4.80$ appearance fee and a flat payment for answering pre- and post-experimental questions (\$8.52 to $\$ 9.84){ }^{22}$ The variable payment was based on both luck (random draw) and participants' investment decisions and could range from $\$ 0$ to $\$ 10$. To allow for comparison, participants across all treatments earned $10 \%$ of the payoff from their investment choices. We held the percentage of individual variable pay constant to rule out that self-serving beliefs or self-regarding (vs. other-regarding) behavior would bias our results (c.f. Haisley and Weber 2010). That is, there is evidence that compensation contracts and certain features thereof (i.e., levels of incentive pay) affect employees' (excessive) risk-taking behavior (e.g., Brink et al. 2017; Dittmann et al. 2011; Kreilkamp et al. 2019). Since our study discusses prosocial features of the firm's incentive system rather than "appropriate" compensation structures, we kept the participants' variable compensation structure constant across conditions. We used a variable compensation scheme to prime participants to think carefully about their investment decisions and reveal their "true" risk-taking behavior (i.e., to ensure incentive compatibility in individual decision behavior). ${ }^{23}$

On average, participants earned $\$ 17.82$ for approximately 100 minutes of participation. ${ }^{24}$ The maximum (minimum) compensation was $\$ 21.17$ (\$14.86). Like the participants' payments, the charitable organizations' points were converted to US dollars at the end of each session. On average, participants earned $\$ 3.57$ on behalf of the charity. The maximum (minimum) donation per participant was $\$ 6.77$ (\$0.60).

\section{Experimental results}

\subsection{Validation of the experimental design}

To verify internal design validity and rule out the possibility of personality-related traits distorting our results, we check for potential sources of overconfidence (Pikulina et al. 2017) and excessive risk-taking (e.g., Nicholson et al. 2005). We observe that both anxiety $(F=10.35, p=0.002)$ and seeking excitement $(F=22.09$, $p<0.001)$ explain participants' risk propensity. However, neither personalityrelated trait significantly differs across treatments, nor do narcissism and striving

\footnotetext{
${ }^{22}$ Participants were paid a piece rate of 3 points or $\$ 0.12$ US dollars per question. The reported range results from a differing number of questions across treatments.

23 To re-examine how a personal stake in the investment outcome impacts excessive risk-taking behavior, another control group would be necessary where only a fixed wage is paid.

${ }^{24}$ We present the means for the full sample (129 participants). The average compensation in the MC sample aggregated to $\$ 17.70$, with a maximum (minimum) compensation of $\$ 20.16$ (\$14.86). Individual remunerations differed similarly from the full sample (baseline $\$ 16.78$; giving treatments $\$ 18.08$, $p<0.001)$.
} 
for achievement (all $p>0.479$ ). Consequently, randomization appears successful: idiosyncratic influences should not interfere with our conclusions.

Using post-experimental questions, we confirm that the level of employee empowerment continuously rises, starting from a social norm-based influence on corporate level (H1) to personal responsibility on project level (H2), and ending with personal involvement, when employees pick the charity (H3). The first question asked participants to indicate agreement with the statement that they felt the firm empowers its employees. Participants' mean responses on a scale ranging from one (strongly disagree) to 11 (strongly agree) increase from 7.93, for no giving, to 9.16 , for charity selection and differ significantly across treatments $(F=2.29, p=0.084)$. Notably, the no-giving condition participants' answers differ significantly from those in the three giving treatments $(t=-2.31$, $p=0.023$ ), with answers significantly higher under the project-level giving and charity selection conditions $(t=-2.40, p=0.019)$. The second Likert scale-item asked participants to indicate to what extent they felt they played a part in the firm's goals and activities (one $=$ very untrue of me; $11=$ very true of me). Participants' mean response of 7.86 (9.00), when giving is absent (present) $(t=-2.98, p=0.004)$ and ANOVA statistics $(F=3.03, p=0.033)$ provide corroborating evidence of distinct levels of perceived organizational commitment and employee empowerment across conditions.

Prior research shows that employees who are primarily motivated by a "mission" or attach meaning or purpose to their job are happier, exert more effort, and accept lower wages (Pratt and Ashforth 2003; Prendergast 2007). Therefore, for our manipulation to be successful, it is crucial that participants consider the charity's mission and work worthwhile and attach meaning to their decisions on risky prospects (Carpenter and Gong 2016). Indeed, we find that participants in the corporate- and project-level giving conditions (charity selection condition) expressed the deservingness of the American Red Cross (their chosen charity). They rated the charity's mission and work positively, as suggested by the mean response of 9.09 (9.92) which is significantly greater than the scale midpoint $(t=11.02(t=13.09)$, both $p<0.001)$. We conclude that our manipulation was successful and induced meaningfulness at work.

\subsection{Descriptive statistics and hypotheses tests}

Our primary dependent variable, excessive risk allocation, is measured as the proportion invested in investment alternative B (risky lottery). Table 2 reports the number of participants per treatment, the means, and standard deviations for all four treatments. Figure 3 illustrates the mean excessive risk allocation for our four treatments and all rounds graphically. Over the ten rounds, the average excessive risk allocation is lowest under the project-level giving program (36.25 points), higher under charity selection (42.04 points). It is highest under no-giving (47.23 points) and the corporate-level giving program (48.71 points).

Beyond these between-treatment effects, we also observe marked round effects. Comparing the first and last rounds, participants become more risk-seeking over time across all conditions (rounds one to five, 41.77 points; rounds six to ten, 45.37 points, $t=-1.78, p=0.075$ ). Additionally, a relatively strong risky shift emerges in the corporate-level giving (rounds one to five, 46.51 points; rounds six to ten, 


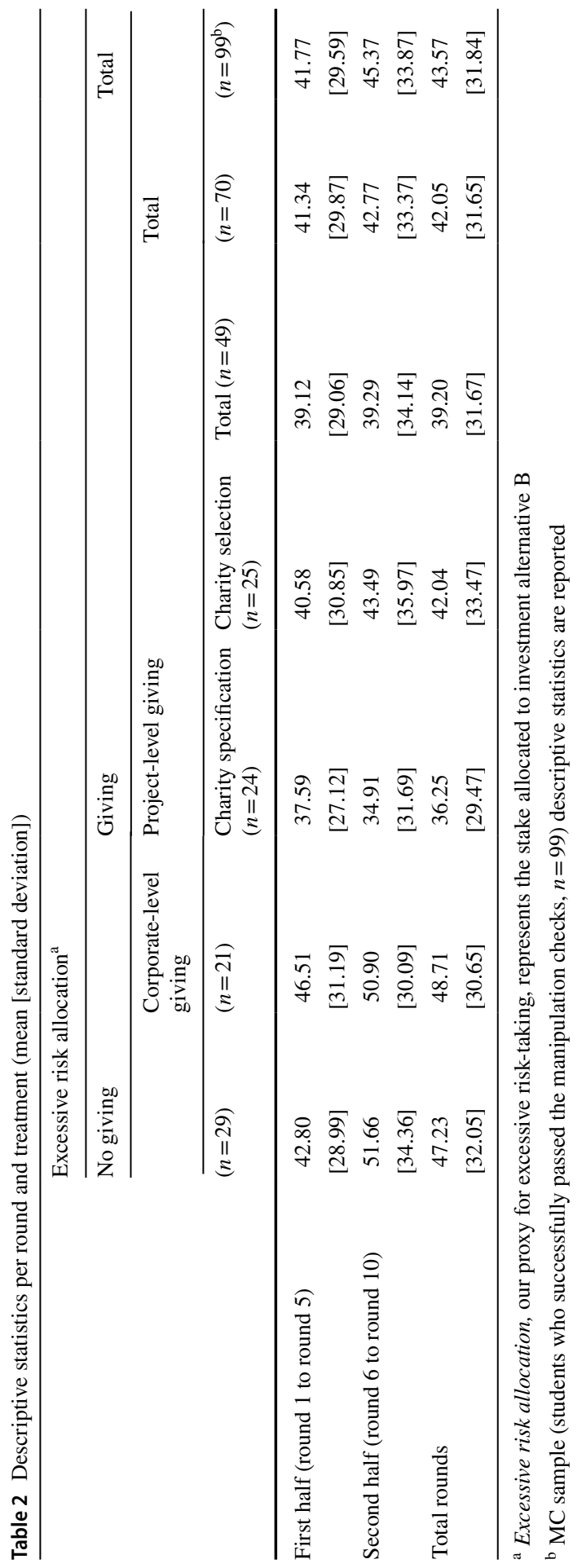


50.90 points, $t=-1.04, p=0.301$ ) and the no-giving treatment (rounds one to five, 42.80 points; rounds six to ten, 51.66 points, $t=-2.37, p=0.018)$. In contrast, the excessive risk allocation for participants in the project-level giving treatment, where the firm's senior management determines the charity, remains comparatively low (rounds one to five, 37.59 points; rounds six to ten, 34.91 points, $t=0.70, p=0.482$ ). Participants who select their charity of choice are moderately willing to take more excessive risks over time (rounds one to five, 40.58 points; rounds six to ten, 43.49 points, $t=-0.69, p=0.494)$. Preliminary indications suggest that relative to the other treatments, project-level giving appears to be the most effective design for reducing excessive risk-taking, both in the short and long term.

To test our hypotheses, we performed a repeated-measures analysis of covariance (RMANCOVA), with the number of points invested in investment alternative B (the risky lottery) as our dependent variable. Our first independent variable is corporate giving, measured in four ways: (i) no giving, (ii) corporate-level giving, (iii) project-level giving, and (iv) charity selection. The second independent variable, round, is our within-subject factor. The analysis includes the ex-ante (ex-post) measured financial risk propensity (level of altruism). Specifically, we use factor analysis to aggregate six items measuring participants' financial risk propensity into a single financial risk-propensity factor (eigenvalue $=2.35$; explained variance $=0.80$ ). Our measure of individual altruism is derived from Rushton et al.'s (1981) self-reported altruism scale, focusing on those items most related to charitable donations and prosocial behavior. The original self-report altruism scale (Rushton et al. 1981) is an instrument designed to elicit previous prosocial behavior, including donating money to charity. We calculate Cronbach's alpha to assess the inter-item covariance for all the item pairs and determine the constructed scale's reliability. ${ }^{25}$ Next, we use factor analysis to combine the six items into a single altruism factor (eigenvalue $=1.78$; explained variance $=1.20$ ). Table 3 presents the computed principal factors for financial risk propensity and altruism.

Table 3, Panels A to D, shows the RM-ANCOVA results from our hypotheses tests. We find both financial risk propensity and the level of altruism, our covariates, to be significantly related to the excessive risk-taking decision (financial risk propensity, $F=11.87$, $p<0.01$; altruism, $F=4.48, p=0.03$ ). Furthermore, the effects of the presence and type of the corporate giving program ("giving") on participants" excessive risk allocations are statistically significant $F=8.14, p<0.01) .{ }^{26}$ We employ contrast coding as a post-estimation

\footnotetext{
25 While we identify ten items, the highest alpha value is obtained if four items with factor loadings below 0.4 are dropped step by step (ten items, $\alpha=0.6823$; six items, $\alpha=0.7214$ ). The resulting altruism factor consists of the following six items: 1) "I have given money to a charity.", 2) "I have given money to a stranger who needed it (or asked me for it).", 3) "I have donated goods or clothes to a charity.", 4) "I have done volunteer work for a charity.", 5) "I have bought 'charity' Christmas cards deliberately because I knew it was a good cause.", and 6) "I have offered my seat on a bus or train to a stranger who was standing." For all items, a higher 11-point Likert score response represents a greater frequency of having carried out the altruistic acts. Since one established motive for charitable contributions is pure altruism, we control for individual altruism. Altruistic or prosocial behavioral intentions reflect a person's readiness to improve the well-being of others, most notably of charitable recipients deserving of funding (Bekkers and Ottoni-Wilhelm 2016).

26 The main effect of the presence and type of the corporate giving program ("giving") is also significant $(F=3.62, p=0.01)$ in an RM-ANCOVA post-estimation test of the full sample. Moreover, the main effect for round becomes significant $(F=2.07, p=0.03$ ) for the full sample (vs. $F=1.23, p=0.28$ in the MC sample).
} 
test to examine the predicted treatment and time effects. Hypothesis H1 is stated in the null and posits that, relative to no giving, excessive risk-taking is not lower if corporatelevel giving is present. While we find "giving" to have a significant impact on excessive risk-taking ( $F=8.14, p<0.01$, Panel A), we fail to find evidence to support that corporate-level giving decreases excessive risk-taking $(F=0.15, p=0.69$, Panel B). Charitable giving at the overall corporate level—a widespread practice-emphasizes senior management's CSR objectives. However, these objectives may not be salient for employees, and they may be too far removed to spill over to their investment decision-making. We further employ the method of orthogonal polynomial contrasts to test for a linear trend. As reported in Panel C, the interaction effect between corporate-level giving vs. no giving and round is insignificant $(F=1.19, p=0.28)$. Hence, participants' excessive risk allocation is not significantly different over time between the no giving and the corporate-level giving treatment (i.e., no systematic different linear time trends). Collectively, H1 is not validated (i.e., cannot be rejected) by the experiment.

Recall that our second hypothesis predicts lower excessive risk-taking when charitable giving is directly linked to individual project performance rather than overall firm profit. As depicted in Table 4, Panel B, the contrast analysis indicates a significant main effect of project-level giving $(F=17.38, p<0.001) .{ }^{27}$ The insignificant interaction between project-level giving vs. corporate-level giving and round (Panel C) indicates that this is not a one-time effect $(F=0.56, p=0.46)$, thus providing full support for H2. Participants' excessive risk allocations in the project-level giving design remain consistently below corporate-level giving design participants. We conclude that project-level giving is effective and persistent in moderating excessive risk-taking behavior. The project-level incentive contract remains salient to the employee, and we do not observe a diffusion of personal responsibility in the short or long term. The perceived accountability effect of project-level giving appears to be long-lasting.

When developing H1, we argue that senior management's decision to implement a corporate-level giving program creates a social influence and activates a social norm of other-regarding behavior in employees. The mediation model in Fig. 1 investigates the effect of the presence of a corporate giving program on excessive risk allocations mediated by social norm activation. While we find that social norm activation significantly diminishes employees' excessive risk allocations (Link 2b: $p<0.001$ ), both the direct (Link 1: $p=0.12$ ) and indirect effect of the presence of a corporate giving program on social norm activation (Link $2 \mathrm{a}:=p=0.53$ ) are insignificant. Importantly, when we replace social norm activation with employees' perceived accountability (Fig. 2), the indirect effect of the type of the corporate giving program on employees' excessive risk allocations is significant (Link $2 \mathrm{a} \times$ Link $2 \mathrm{~b}$; $p=0.08 \times 0.01$ ), while the direct effect is still insignificant (Link $1 ; p=0.66$ ). We

\footnotetext{
27 This result remains significant $(F=7.22, p=0.01)$ in an RM-ANCOVA post-estimation test of the full sample.
} 


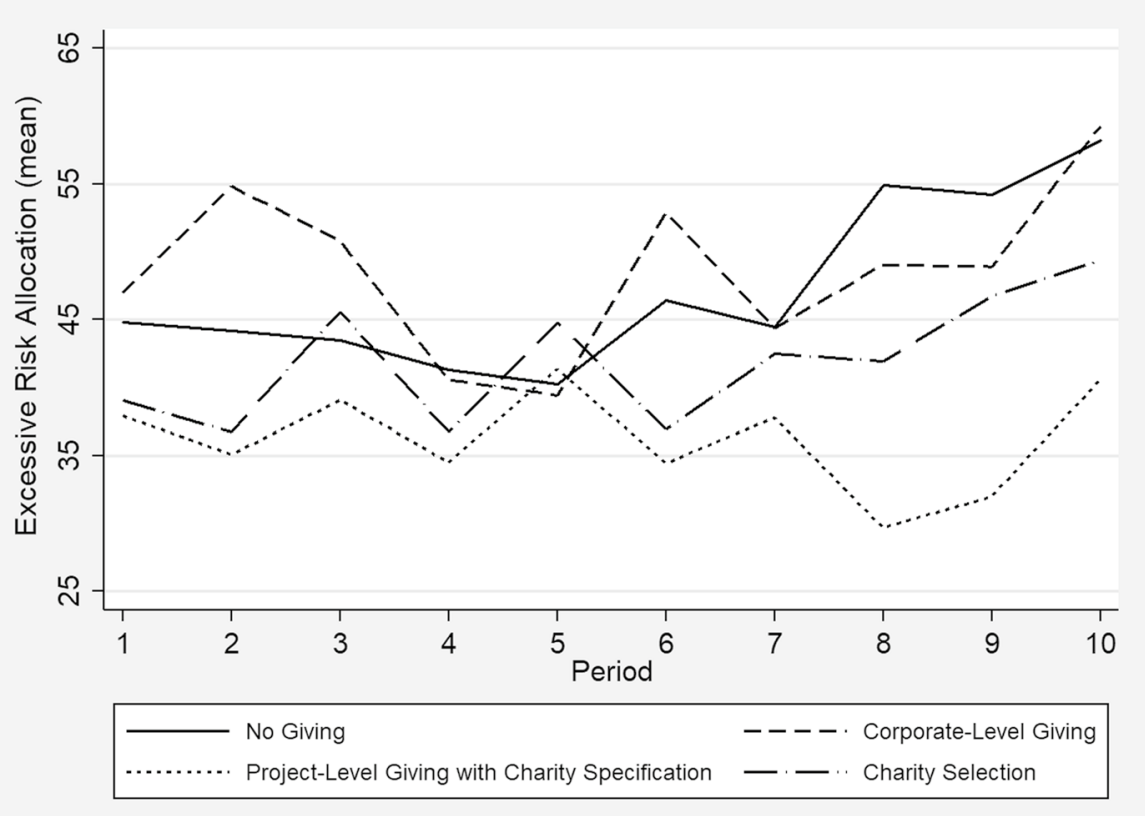

Fig. 3 Descriptive statistics per round and treatment (mean). It illustrates the means of the Excessive risk allocation (i.e., the stake allocated to investment alternative B) per round and treatment of the MC sample $(n=99)$

infer full mediation. These results are entirely congruent with the statistical support of $\mathrm{H} 2$.

Our third hypothesis addresses whether employees' excessive risk decisions are influenced by who selects the charity as the project's payoff beneficiary (the firm vs. the employee). Table 4, Panels A to C, presents the RM-ANCOVA results. Consistent with our initial descriptive analysis and our reasoning, participants make larger excessive risk allocations when selecting their charity relative to when senior management selects the beneficiary charity. We observe a marginal statistically significant risky shift $\left(F=2.87, p=0.09\right.$, Panel B) ${ }^{28}$ This effect does not vanish over time, as indicated by the insignificant interaction charity selection vs. project-level giving $\times$ round $(F=1.43, p=0.23$, Panel $C)$. When employees are empowered to choose the benefiting charity, we find that firms are more likely to suffer from excessive risk-taking behavior. We conclude an inverted U-shaped curve of effectiveness so that employee selection of the beneficiary may negate project-level giving benefits. Hence, we identify a potential drawback of corporate giving programs that employees actively participate in, as outlined in current charitable giving reports (e.g., Giving USA Foundation ${ }^{\mathrm{TM}}$ 2017). This result is notable as it implies that personal

28 This result remains significant only on a one-tailed basis $(F=2.01, p=7.85$, one tailed) in an RMANCOVA post-estimation test of the full sample. 
Table 3 Aggregate responses to pre- and post-experimental items (mean [standard deviation])

\begin{tabular}{|c|c|c|c|c|c|c|}
\hline \multirow[t]{2}{*}{ No giving } & \multicolumn{5}{|l|}{ Giving } & \multirow[t]{2}{*}{ Total } \\
\hline & $\begin{array}{l}\text { Corporate- } \\
\text { level } \\
\text { giving }\end{array}$ & Project-level q & iving & & Total & \\
\hline$(n=29)$ & $(n=21)$ & $\begin{array}{l}\text { Charity } \\
\text { specification } \\
(n=24)\end{array}$ & $\begin{array}{l}\text { Charity } \\
\text { selection } \\
(n=25)\end{array}$ & Total $(n=49)$ & $(n=70)$ & $(n=99)$ \\
\hline
\end{tabular}

Panel A: Domain-specific risk factor $(n=99)$

\begin{tabular}{|c|c|c|c|c|c|c|c|}
\hline Financial & -0.16 & 0.04 & 0.04 & 0.12 & 0.08 & 0.07 & 0.00 \\
\hline $\begin{array}{l}\text { risk } \\
\text { propensity, } \\
\text { calculated }\end{array}$ & {$[0.74]$} & {$[0.92]$} & {$[0.98]$} & {$[1.02]$} & {$[0.99]$} & {$[0.97]$} & {$[0.91]$} \\
\hline \multicolumn{8}{|c|}{ Panel B: Self-reported altruism factor $(n=99)$} \\
\hline \multirow{2}{*}{$\begin{array}{l}\text { Altruism, } \\
\text { calculated }\end{array}$} & 0.07 & -0.10 & -0.12 & 0.12 & 0.00 & -0.03 & 0.00 \\
\hline & {$[0.79]$} & {$[0.81]$} & [0.84] & [0.94] & [0.89] & {$[0.86]$} & [0.84] \\
\hline
\end{tabular}

Panel A reports participants' financial risk propensity, a synthesis of six items from the DOSPERT scale (financial risk domain) and included in the pre-experimental questionnaire. The answers are provided on an eleven-point Likert scale, with a high score representing a greater tendency to take risks. The (z-standardized) variable Financial Risk Propensity is calculated using principal factor analysis (eigenvalue $=2.35$; explained variance $=0.80$ )

Panel B reports participants' level of altruism, a synthesis of six items taken from the self-reported altruism scale and included in the post-experimental questionnaire. The answers are provided on an elevenpoint Likert scale, with a high score representing a higher frequency of altruistic behavior $(1=$ never; $11=$ every time). The (z-standardized) variable Altruism is calculated using principal factor analysis $($ eigenvalue $=1.78$; explained variance $=1.20)$

involvement in designating the recipient charity ("employee CSR-empowerment") may encourage employees to engage in risk-seeking behaviors in the hope of a lowprobability but high payoff.

\subsection{Additional analyses}

\subsubsection{The subsample of risk-averse and risk-neutral participants}

This section replicates our tests for risk-averse and risk-neutral participants to further substantiate the theory backing our results. Risk aversion is a fundamental premise of the principal-agent theory and a core element in standard theories of lottery choice, asset valuation, or contracts (Holt and Laury 2002). However, the ex-ante classification of risk-averse and risk-neutral versus risk-seeking individuals is not uniquely dichotomous. As a general rule, individuals are expected to be risk-averse; there is no universal approach to measure an individual's risk aversion (Kreilkamp et al. 2020).

We classify participants as risk-averse based on our measure for financial risk propensity. Recall, our measure for a participant's financial risk propensity is an aggregated factor of six survey items taken from the DOSPERT scale (Blais and 
Table 4 Hypotheses tests

\begin{tabular}{|c|c|c|c|c|c|}
\hline Source of variation & df & \multicolumn{2}{|c|}{ Mean squared } & $F$-statistic & $p$-Value \\
\hline \multicolumn{6}{|c|}{ Panel A: Repeated-measures ANCOVA results. Dependent variable: excessive risk allocation ${ }^{\mathrm{e}}(n=99)$} \\
\hline \multicolumn{6}{|l|}{ Between subjects } \\
\hline Giving $^{\mathrm{a}}$ & 3 & 8,03 & & 8.14 & $<0.001 * * *$ \\
\hline Financial risk propensity ${ }^{\mathrm{b}}$ & 1 & 11,7 & & 11.87 & $<0.001 * * *$ \\
\hline Altruism $^{c}$ & 1 & 4,42 & & 4.48 & $0.0346^{* *}$ \\
\hline \multicolumn{6}{|l|}{ Within subjects } \\
\hline Round $^{\mathrm{d}}$ & 9 & 1,2 & & 1.23 & 0.2751 \\
\hline Giving $\times$ round & 27 & & & 0.52 & 0.9804 \\
\hline Residual & 487 & & & & \\
\hline \multicolumn{6}{|c|}{$R^{2}=0.0657$, Adjusted $R^{2}=0.0253$} \\
\hline Contrasts of marginal linear & Givir & & df & $F$-Statistic & $p$-Value \\
\hline \multicolumn{6}{|c|}{ Panel B: Adjacent contrast comparison for Excessive Risk Allocation $(n=99)$} \\
\hline \multicolumn{3}{|c|}{ Effect of corporate-level giving vs. no giving } & 1 & 0.15 & 0.6939 \\
\hline \multicolumn{3}{|c|}{ Effect of project-level giving vs. corporate-level giving } & 1 & 17.38 & $<0.001 * * *$ \\
\hline \multicolumn{3}{|c|}{ Effect of charity selection vs. project-level giving } & 1 & 2.87 & $0.0905^{*}$ \\
\hline \multicolumn{3}{|l|}{ Denominator } & 948 & & \\
\hline
\end{tabular}

\begin{tabular}{llll}
\hline Contrasts of marginal linear predictions: Round & df & $F$-Statistic & $p$-Value
\end{tabular}

Panel C: Polynomial orthogonal contrasts test for a linear trend $(n=99)$

Effect of round (i.e., linear trend)

Interaction effect of corporate-level giving vs. no giving $\times$ round (i.e., linear trend)

Interaction effect of project-level giving vs. corporate-level giving $\times$ round $\quad \begin{array}{llll}1 & 0.56 & 0.4559\end{array}$ (i.e., linear trend)

$\begin{array}{llll}\text { Interaction effect of charity selection vs. project-level giving } \times \text { round (i.e., } \quad & 1 & 1.43 & 0.2317\end{array}$ linear trend)

$\begin{array}{llll}\text { Interaction effect giving } \times \text { round (i.e., linear trend) } & 3 & 1.31 & 0.2709\end{array}$

Denominator 948

\begin{tabular}{lccc}
\hline Contrasts of marginal linear predictions & df & $F$-Statistic & $p$-Value \\
\hline Panel D: Simple effects-polynomial orthogonal contrasts test for a linear trend (n=99) & \\
Effect of round (i.e., linear trend) within no giving & 1 & 6.20 & 0.0130 \\
Effect of round (i.e., linear trend) within corporate-level giving & 1 & 0.43 & 0.4915 \\
Effect of round (i.e., linear trend) within project-level giving & 1 & 0.13 & 0.7219 \\
Effect of round (i.e., linear trend) within charity selection & 1 & 1.81 & 0.1784 \\
Joint & 4 & 2.15 & 0.0725 \\
Denominator & 948 & &
\end{tabular}

$*, * *$, and $* * *$ indicate significance at the $0.10,0.05$, and 0.01 levels, respectively (two-tailed)

${ }^{a}$ Giving is the presence and type of the corporate giving program and is manipulated between subjects. In Condition 1, our baseline, there is no charitable giving. Overall firm profit is distributed to an anonymous group of investment decision beneficiaries. In condition 2, corporate-level giving, $10 \%$ of firm earnings are donated to the American Red Cross. In condition 3, project-level giving, $10 \%$ of each participant's project outcome is donated to the American Red Cross. In Condition 4, participants select a charity from a list of 10 to which $10 \%$ of individual project outcome is donated 
Table 4 (continued)

${ }^{\circ}$ Financial Risk Propensity, our measure for participants' risk propensity in the financial decision domain, is derived through principal factor analysis. One strong factor is retained (see Table 3, Panel A)

'Altruism, our measure for participants' prosocial disposition, is derived through principal factor analysis. One strong factor is retained (see Table 3, Panel B)

${ }^{\mathrm{d}}$ Round is a within-subjects factor. Two trials and ten rounds of the experiment are conducted

${ }^{\mathrm{e}}$ Excessive Risk Allocation, our dependent variable and proxy for excessive risk-taking, is the number of points allocated to investment alternative $B$

Weber 2006) that participants had responded to at the experiment's outset, i.e., before they experienced the experimental manipulation. We recode this continuous factor that ranges from minus one to one into groups (i.e., $p$-percentile) and set it at the $75 \%$ percentile to differentiate between risk-averse or risk-neutral and riskseeking participants. Consequently, 74 participants form the risk-averse and riskneutral subsample, while this sample split categorizes the remaining participants as risk-seeking.

On average, the subsample of risk-averse and risk-neutral participants allocated 41.28 points to investment alternative B. Depending on the corporate giving program, there are significant differences as revealed by an RM-ANCOVA $(F=6.78$, $p<0.001)$. Consistent with our main analysis, a risk-averse and risk-neutral participant's average excessive risk-taking behavior is lowest in the project-level giving condition (32.29 points) and higher in any other condition (no giving: 45.48 points, corporate-level giving: 45.13 points, charity selection: 42.40 points). To validate the robustness of our main results, we perform a contrast analysis as a post-estimation test (H1: $F=0.11, p=0.744 ; \mathrm{H} 2: F=14.57, p<0.001 ; \mathrm{H} 3: F=8.39, p=0.004)$. We next subdivide the MC sample by the $90 \%$ percentile such that the upper $10 \%$ bound of risk-seekers are excluded and replicate the tests. Our results are inferentially identical with the project-level giving effect statistically more significant (H1: $F=1.95$, $p=0.163 ; \mathrm{H} 2: F=25.46, p<0.001 ; \mathrm{H} 3: F=7.19, p<0.008) .{ }^{29}$

\subsubsection{The subsample of risk-seeking participants}

To better understand the project-level giving program's effectiveness in constraining excessive risk-taking, we investigate whether giving at the project level reduces excessive risk-taking of risk-seeking individuals or whether this risk-reduction effect materializes only for already risk-averse or risk-neutral individuals. Recall, projectlevel giving introduces perceptions of accountability such that the individual feels personally responsible for the project payoff. Prior literature on accountability already provides evidence that the requirement to justify one's decision (i.e., external accountability) is a prevalent risk management technique (Lefebvre and Vieider

\footnotetext{
29 If we replace the factor for financial risk propensity by the simple average of the corresponding six DOSPERT scale items, the conclusions as shown in this section remain robust. Essentially, as the factor for financial risk propensity is formed based on these scale items, both measures are highly positively correlated $(r=0.9929)$.
} 
2013; Schedlinsky et al. 2018). If held accountable for their choices, the idea is that decision-makers choose the options easiest to justify towards themselves and others. However, individuals who prefer high-risk options may have a more robust return focus and are less likely to shrink from an excessive risk investment (Kreilkamp et al. 2020). They may interpret justification as a weaker signal to reduce risk under a project-level giving contract. Thus, whether the risk-reduction effect revealed by our RM-ANCOVA also extends to the risk-seeking subsample is not apparent.

At each $p$ - percentile of our measure for financial risk propensity, untabulated predictive margins steadily estimate the average excessive risk allocation to be lower in the project-level giving condition than in any other condition. ${ }^{30}$ The estimated excessive risk allocation increases continuously with higher financial risk propensity over all conditions. However, the pattern for each percentile of financial risk propensity remains stable, with project-level giving always lowest and corporate-level giving always highest. Like our RM-ANCOVA results, the predictive margins suggest that effective risk-seeking behavior mitigation requires giving by the individual employee, occurring at project level (lower organizational level). Giving at the overall corporate-level does not appear to impact an employee's excessive risk-taking decisions.

\subsubsection{Ex-ante financial risk propensity vs. excessive risk-taking behavior}

Of those participants in our risk-averse or risk-neutral subsample, 14 exhibit an excessive risk-seeking behavior in the main task and are among the riskiest participants in the investment task (i.e., in the top 25\% percentile)—despite their dispositional risk aversion or neutrality. The literature provides two explanations for this incongruity. First, individuals are usually not identically classified by different riskelicitation methods (Lönnqvist et al. 2015). Second, an individual's financial risk propensity does not necessarily translate into actual excessive risk-taking behavior. One part of an individual's financial risk propensity is dispositional, whereas the other part is adaptable to the situation (i.e., affected while performing the investment task). To rule out the possibility that these participants bias our results and to provide a conservative test for our theory, we eliminated these 14 observations and re-performed the test of $\mathrm{H} 2$. This procedure precludes the possibility that the riskreduction effect observed for the project-level giving program results from (nonrisk-seeking) participants in the corporate-level giving treatment taking extraordinarily high levels of risk. While this helps to isolate the psychological explanation from alternative explanations, we also find inferentially identical results when these

\footnotetext{
${ }^{30}$ For example, if the average participant falls into the 90 percent percentile, we estimate an excessive risk allocation of 40.46 points for project-level giving, whereas the estimated excessive risk allocation rises to 45.30 points for charity selection and amounts to 52.84 points ( 51.72 points) for corporate-level giving (no giving).
} 
participants are removed, and the adjacent contrast comparison for $\mathrm{H} 2$ (untabulated) turns even more significant $(F=23.82, p<0.001)$.

\subsubsection{Participants' assessment of a risky decision situation}

Sitkin and Pablo (1992) postulate that, in addition to framing, the organizational risk culture and leader risk orientation can shift an individual's risk perception relative to his initial risk propensity. We assume and find that corporate giving frames the decision-making situation such that participants become more risk-averse relative to the no-giving condition. The three giving treatment conditions exhibit a significant cautious shift (risk propensity score (ex ante): mean $=6.02$; risk perception score (ex post): mean $=4.70 ; t=5.13, p<0.001) .{ }^{31}$ That is, participants reported perceiving larger losses than before the experiment. This cautious shift in participants' risk perceptions is notable since it indicates that CSR, as operationalized by corporate giving, is associated more with low- than high-risk investment activities. Answers to post-experimental questionnaire items corroborate this conclusion. Specifically, participants' mean response to the question of whether they thought that charitable giving could alter one's risk attitude on an 11-point Likert scale (one= very unlikely; $11=$ very likely) of 8.42 differs significantly from the midpoint of six $(t=11.85$, $p<0.001)$. Second, the participants responded to the question whether charitable giving should be oriented more toward low-risk than high-risk decisions with a mean of 8.16 on an 11-point Likert scale ranging from one (strongly disagree) to 11 (strongly agree). Again, agreement to this question is significantly higher than the midpoint of six $(t=8.20, p<0.001)$, which further substantiates our assumption that exercising risk-aversion when deciding on behalf of a charitable cause is generally accepted behavior (e.g., the social norm). ${ }^{32}$ The significant shift in participants' risk perceptions and their post-experimental responses support the argument that charitable giving makes a contextual difference in how employees perceive risk when making decisions, thereby altering their incentive package.

\subsubsection{The subsample of prosocially-motivated participants}

Prosocial incentives can be first and foremost motivating for prosocially-motivated employees. Henceforth, we classify a participant as "prosocially motivated" if he derives direct utility from the charitable giving program's impact, independent of any signaling properties (Besley and Ghatak 2005; Cassar and Meier 2017). It follows that it would be interesting to see whether employees to whom giving to charity is important respond differently to corporate giving-practices than employees

\footnotetext{
31 To compare participants' risk propensity (ex ante) with their risk perception (ex post) the scale items for determining the cautious shift are identical for both personality variables. The items are (cf. Blais and Weber 2006) 1) "Disagreeing with an authority figure on a major issue", 2) "Betting a day's income at a high-stake poker game", 3) "Investing ten percent of your annual income in a new business venture", and 4) "Choosing a career that you truly enjoy over a more secure one.".

32 In addition, there are no significant differences between treatments $(F=0.36, p=0.78 ; F=1.19$, $p=0.32$ ).
} 
who do not consider charitable giving important. The idea is that since prosociallymotivated employees care about a charitable cause directly, they work harder (Fehrler and Kosfeld 2014) or lower their reservation wages (Burbano 2016) to support the mission of that cause. Therefore, it is logical to assume that a charitable giving program also influences the excessive risk-taking behavior of those employees to whom giving to charity is important.

An 11-point Likert-scale item placed in the post-experimental questionnaire in the corporate- and project-level giving conditions (charity selection condition) asks about the extent to which the recipients of donations to the American Red Cross (their chosen charity) are deserving of support (one=strongly disagree; $11=$ strongly agree). We rate participants with responses greater than or equal to ten as socially responsible. We create an indicator variable equal to one for prosociallymotivated participants and zero otherwise. The results are inferentially identical when we include this variable in the RM-ANCOVA and subsequent post-estimation tests for substantiating $\mathrm{H} 2$ and $\mathrm{H} 3$. In detail, the adjacent contrast comparisons for $\mathrm{H} 2(F=13.25, p<0.001)$ and for H3 $(F=3.42, p=0.065)$ (both untabulated) still yield significant effects regarding the type of the charitable giving program.

To better understand the $\mathrm{H} 3$ results, it is helpful to know the type of charities that the employees choose, as this choice could impact the results, given that the charities have diverse missions and scope. Specifically, charities differ in location (local vs. national vs. global) and/or in type (e.g., food security, special needs). From this it follows that it would be insightful to understand whether employees with preferences for the American Red Cross (and charities similar in scope) respond differently to corporate giving practices in terms of excessive risk-taking behavior than employees with preferences for other charities. ${ }^{33}$ Consequently, this additional analysis refers to the charity selection condition. We recognize that the results may reflect the excessive risk-taking behavior of the individual's characteristics who selects the charity. Different responses could also be explained by the notion that the personal benefits of prosociality depend on the context, i.e., the characteristics of the recipient (Brown et al. 2017; List 2007).

Table 5, Panel A shows the charities chosen by those participants assigned to the charity selection condition, and Table 5, Panel B displays the results of a twosample t-test. We formed groups based on the charity type (health and food security vs. animal welfare and youth development). The pairwise comparison of these groups shows significant differences in excessive risk-taking behavior. Participants who choose a charity providing food and medical care (e.g., disaster relief) like the American Red Cross allocated much less to the investment alternative B over all rounds. Participants choosing a charity promoting animal welfare or educational services exhibit significantly more excessive risk-taking behavior. These findings should be interpreted in the light of the observation that urgently needed aid and extreme poverty motivate altruism and more general welfare criteria (Brañas-Garza

\footnotetext{
33 Note that the choice of charity is endogenous only in the charity selection condition, while the charity (i.e., American Red Cross) in the corporate-level giving and project-level giving conditions is senior management-specified.
} 
Table 5 Descriptive statistics and comparison of means by charities chosen

\begin{tabular}{|c|c|c|c|c|c|}
\hline Name of charity & Charity location & Charity type ${ }^{b}$ & \multicolumn{2}{|c|}{ Times selected } & Percent \\
\hline \multicolumn{6}{|c|}{ Panel A: Summary-donations to charities } \\
\hline $\begin{array}{l}\text { American Cancer } \\
\text { Society }\end{array}$ & Non-Local & Health & \multicolumn{2}{|l|}{0} & 0 \\
\hline American Red Cross & Non-Local & Health & 2 & & 8 \\
\hline Big Brothers Big Sisters & Non-Local & Youth Development & 3 & & 12 \\
\hline $\begin{array}{l}\text { Doctors Without } \\
\text { Borders }\end{array}$ & Non-Local & Health & 5 & & 20 \\
\hline Feed The Children & Non-Local & Food Security & 1 & & 4 \\
\hline Next Door Foundation & Local & Youth Development & 2 & & 8 \\
\hline Oxfam Americal & Non-Local & Food Security & 2 & & 8 \\
\hline Sierra Club & Non-Local & Animal welfare & 2 & & 8 \\
\hline $\begin{array}{l}\text { Wisconsin Humane } \\
\text { Society }\end{array}$ & Local & Animal welfare & 7 & & 28 \\
\hline YMCA (the Y) & Non-Local & Youth Development & 1 & & 4 \\
\hline \multicolumn{3}{|l|}{ Total } & 25 & & 100 \\
\hline Charity type ${ }^{b}$ & & in [standard devia- & Standard error & $t$-statisti & $p$-value $\left.{ }^{c}\right]$ \\
\hline \multicolumn{6}{|c|}{ Panel B: t-Test by the charity type. Dependent variable: mean excessive risk allocation ${ }^{\mathrm{a}}(n=25)$} \\
\hline Health/food security & 15 & $50.62[22.41]$ & 5.79 & & \\
\hline $\begin{array}{l}\text { Youth development/ } \\
\text { animal welfare }\end{array}$ & 10 & 29.16 [20.49] & 6.48 & & \\
\hline \multicolumn{2}{|l|}{ Difference } & 21.46 & 8.85 & \multicolumn{2}{|c|}{$2.42[0.012]$} \\
\hline
\end{tabular}

Degrees of freedom $=23$

${ }^{a}$ Mean excessive risk allocation is the average number of points that a participant allocates to investment alternative B, the excessive risk option, over all ten experimental rounds. The number of points allocated to investment alternative $\mathrm{B}$ is our measure for excessive risk-taking

b Charity type refers to the charitable organizations' mission and scope of work. We identified four distinct types of charities, i.e., health, food security, youth development and animal welfare. An indicator variable equals 1 if a charity's mission focuses on health or food security, and 0 otherwise. We watch out for including both local and national as well as global charities with varying missions to fully match the interests and preferences of the participants. There is some evidence to suggest that participants' choice of charity is impacted by its geographical proximity, its familiarity as well as its mission and its goals (e.g., Brown et al. 2017)

${ }^{\mathrm{c}} p$-values are reported two-tailed

2006) - appealing to an employee's sense of responsibility and thus eliciting more restrained risk-taking decisions. For example, participants in laboratory dictator games give nearly three times more when the recipient is the American Red Cross (i.e., "a recipient generally agreed to be 'deserving",) than an anonymous recipient (Eckel and Grossman 1996).

Finally, these results highlight the importance of considering the recipients on behalf of whom excessive risk is taken and of differentiating between the primary performance components of risk and effort. While Altenburger (2020) and others (e.g., Tonin and Vlassopoulos 2010, 2015) show that participative corporate giving 
or incentive structure choice increases employee performance (via effort), our study suggests that too much participation may backfire and crowd-in motivated reasoning, which could potentially trigger excessive risk-taking behavior. However, if the social cause supports a mission in urgent need of financial help to provide for shelter, food and first aid, and other disaster relief services (i.e., as soon as essentials are at risk), excessive risk-taking stakes decline significantly. Our results conform to those of the prior research which generally advocates more choice and employee participation in corporate giving practices.

\section{Discussion and conclusion}

\subsection{General discussion}

Incentive contracts are crafted to align the interests of principals and agents (Luft and Shields 2009). While tournament and short-term incentive contracts have been used extensively, both suffer from creating excess risk-taking incentives. We argue that CSR initiatives, like corporate giving programs, can be an effective component in an incentive contract in that they provide a remedy for excessive risk-taking. Salazar et al. $(2012,176)$ argue that "approaches to firm-level social performance evaluation hide the real relationships between the social activity and its consequences for firm economic performance and social impacts." Our results suggest that individual compensation plans that link project outcomes to corporate giving programs reveal this real relationship and thus appear promising. Charitable contributions at the project level diminish employees' excessive risk-taking, and importantly, this effect persists over time. We show that employees are relatively riskier in the short and long term when a global metric (i.e., not the individual employee) is emphasized; the corporate giving policy is perceived as the senior management's responsibility. Indeed, our mediation model identifies employees' perceived accountability as the mechanism through which the structure of a corporate giving program constrains excessive risk-taking. Making employees personally responsible for charitable giving enhances the perceived responsibility for and the impact of helping, thereby reducing excessive risk-taking in the long term. By contrast, corporate-level cues are too subtle or remote from the decision-maker to achieve the desired behavioral responses in our setting. We speculate that when employees are responsible for the charity's payoff, the charitable beneficiary becomes more salient and identifiable for them, sticking in employees' memories.

While our setting is charitable giving, our results generalize and highlight that the feeling of controllability is likely to be important (per se) when designing incentives. Employees have a minimal impact on the donation when charitable giving is tied to firm performance. Employee controllability and responses increase when tied to individual projects (Merchant and van der Stede 2017). In the broadest terms, our findings corroborate the view that "CSR is integral to management control systems" (Costas and Kärreman 2013, 395; see also Lueg and Radlach 2016) and influence internal dynamics. Nevertheless, for CSR corporate discourses and practices to be a form of management control 'that ties employees' aspirational identities and ethical 
conscience to the organization" (Costas and Kärreman 2013, 394), employees must see themselves as meaningful agents within their area of responsibility. Consistent with the idea that "all motivation starts with the individual" (Nelson 2018, 14), the firm's incentive system appears to need employees' perceived accountability for other-regarding behavior (and controllability over the outcome) to "cue" or trigger that social norm of other-regarding behavior (Bicchieri 2006). Communicating the firm's objectives via employees' incentive structure (of which charitable donations may be only one part) tends to be insufficient to activate the norm and make employees allocate the firm's resources in its best interests. The firm may have the best corporate-level CSR activities, but if its employees are not motivated by those activities, they will not inform employees' decision-making and, accordingly, not help the firm.

At the same time, care should be taken since too much freedom and empowerment (e.g., choosing the charity) may be counter-effective and "crowd out" reasonable risk-taking behavior. Our data points towards an inverted U-shape curve of effectiveness such that both too little and too much employee empowerment may negate the desirable incentive mechanism (e.g., personal responsibility) of projectlevel giving.

\subsection{Further theoretical and practical implications}

In a related study, Balakrishnan et al. (2011) report that corporate giving motivates employees to contribute to organizational endeavors so that corporate giving pays off financially. Our results extend this finding to the context of excessive risk-taking, where the rational strategy is to take no risk. Our data resonates with Balakrishnan et al.'s (2011) reasoning that senior management should consider both external and internal stakeholder groups when designing prosocial giving programs and their behavioral consequences on excessive risk-taking within the firm. Specifically, our study highlights the effectiveness of more creative solutions than a firm-wide corporate giving program and recommends an alternative possibility for firms to implement CSR initiatives. We suggest that project-level giving serves as a powerful contracting benefit that firms can harness to keep employees from taking excessive risk and encourage them to create shared value. Our experiment expands Bicchieri's (2006) idea that norms influence behavior only when they are salient or focal for the individual at the time of behavior. Because project-level giving is employee-centered-highlighting personal responsibility and individual, rather than a firm-wide agency - this design feature triggers norm-compliant behavior (i.e., taking less excessive risk in a decision also affecting a charitable beneficiary). The firm's corporate giving program seems to require personal responsibility that leads employees to interpret the environment as one to which the norm of other-regarding behavior applies, focus on the norm, and act accordingly. Hence, our study advances the literature exploring the mechanisms via which CSR curbs excessive risk-taking and thus increases firm value (e.g., Harjoto and Laksmana 2018). Following this, our results underline the conventional wisdom that the feeling of controllability is important when designing incentives to produce desired outcomes. Standard 
employee engagement practice takes a passive management control approach, which causes employees to think of what is being done to them rather than what they are doing for themselves is mutually beneficial for others (Nelson 2018). Our investigation addresses the role of controllability and individual agency to influence business activities (that might not necessarily relate to CSR), an important part of moving from aspirations to actions (Corbett et al. 2018; Wolfgramm et al. 2015).

We also contribute to the growing literature stream on risk-taking on others' behalf (Bolton et al. 2015b). Although the traditional economic theory is silent on how risk is taken on another's behalf, we observe less risk-seeking behavior when the risk is taken on behalf of those in need. This finding supports the widely held view that individuals exhibit social preferences when paired with perceived personal responsibility. We present both corporate giving programs that attenuate excessive risk-taking persistently (project-level giving) and others that incentivize greater risktaking (corporate-level giving or charity selection).

Finally, while our experiment examines the effect of different corporate giving programs on excessive risk-taking, the theory on which our predictions are based should extend to a broader set of CSR contracts (with other social welfare or environmental criteria, e.g., emission reduction targets) that tie the pay of employees to project-level performance as well. Our findings may also apply to other forms of dysfunctional decision-making or undesirable employee behavior. For example, the literature on other-regarding preferences indicates that employees abstain from socially-oriented misreporting, cheating, or other fraudulent behavior when the decision benefits a social mission (e.g., Hobson et al. 2019).

\subsection{Limitations and future research}

Our study's limitations provide fruitful avenues for future research. First, the experimental setting used in the current study expects charitable incentives to create a positive signal about the firm's benevolence and trustworthiness. However, both anecdotal and empirical evidence indicate that managers use charitable donations for self-serving interests at the expense of firm value. Brown et al. (2006, 856), for instance, claim that "the [corporate philanthropy] literature is intertwined with the 'social responsibility of business' debate," and Masulis and Reza (2015) document that CEOs misuse firm resources by supporting their preferred charities (i.e., CEO's "pet" projects) through corporate donations. On a related note, Cassar and Meier (2017) find that some prosocial incentives backfire. While these incentives are employed instrumentally to benefit the firm (or the firm's senior management) rather than the charity, future research might explore the mechanisms that lead to a negative signaling value and integrate intentions for doing good or the authenticity of the firm's CSR program into the experimental design (McShane and Cunningham 2012).

Second, our approach proposes that employees' internal motivation is the mechanism to decrease their excessive risk-taking behavior. Since H1 is not validated and $\mathrm{H} 2$ is, we surmise that employees' decrease of excessive risk behavior is a function of their reputation gained from having a more positive net present value project. 
However, since impression management requires an actor and a target audience (Bolino et al. 2016), we do not include the firm's senior management as a "real person" in the experimental setup. To mitigate such impression management or related forms of self-interest or reputational considerations alike, our approach differs from other accounting experiments with employee-employer-groups (e.g., Christ and Vance 2018). Future experiments may use more realistic settings to investigate the firm's senior management role in creating impression management tactics.

Third, to examine time effects (e.g., habituation, fading, or end-round strategies), the outcomes and probabilities of winning the risky investment alternative remain constant over all rounds. Future research could alter the risky investment option's payoff structure to test whether, as postulated by prospect theory, employees' investment behavior turns riskier in the low-probability, high-outcome (high-gain) domain (Pahlke et al. 2015). Further, with the only options of no risk or bad risk, this study ignores the notion that firms will reasonably expect some risk-taking. Additional research could look at risky decision-making with an acceptable expected value above one, yielding a positive net present value project.

Fourth, adding employees' compensation scheme to examine the interplay between the corporate giving design and monetary incentives could provide additional insight into the value employees place on prosocial incentives. In particular, asymmetrical payment structures may prove fruitful, with personal losses limited and employees shielded from their decisions' full negative repercussions (Brink et al. 2017). Finally, cash donations to charity are only one manifestation of a giving program in the workplace. Non-cash workplace giving designs, such as time off to volunteer, have been increasingly popular in practice. Thus, it would be worthwhile analyzing the impact of other workplace giving forms, most notably non-cash ones, on excessive risk-taking behavior.

Supplementary Information The online version contains supplementary material available at https://doi. org/10.1007/s11573-021-01063-8.

Acknowledgements This paper is part of Julia Schneider's dissertation at Justus Liebig University Giessen. We are grateful to this study's participants and the following individuals for their thoughtful comments and valuable suggestions: Deni Cikurel, Thorsten Knauer, Michael Majerczyk, Friedrich Sommer, Laura Swenson, Amy Tegeler, Marcel van Rinsum, and Arnt Wöhrmann, and workshop partners at the University of Wisconsin-Milwaukee, attendees at the 2017 Annual Summer School on Experimental Research in Management Accounting, 2019 Workshop on Experimental and Archival Research in Accounting at Justus Liebig University Giessen, 2019 MBAA International Conference: Cultural Consciousness in Business, 2019 GMARS, 2019 AAA Annual Meeting and 7th Annual Conference on Risk Governance.

Funding Open Access funding enabled and organized by Projekt DEAL.

Data availability Data is available on request.

Open Access This article is licensed under a Creative Commons Attribution 4.0 International License, which permits use, sharing, adaptation, distribution and reproduction in any medium or format, as long as you give appropriate credit to the original author(s) and the source, provide a link to the Creative Commons licence, and indicate if changes were made. The images or other third party material in this article are included in the article's Creative Commons licence, unless indicated otherwise in a credit line to the material. If material is not included in the article's Creative Commons licence and your intended use is 
not permitted by statutory regulation or exceeds the permitted use, you will need to obtain permission directly from the copyright holder. To view a copy of this licence, visit http://creativecommons.org/licen ses/by/4.0/.

\section{References}

Acharya VV, Pagano M, Volpin PF (2016) Seeking alpha: excess risk taking and competition for managerial talent. Finance working paper, European Corporate Governance Institute (ECGI) 2014. https:// doi.org/10.2139/ssrn.1786699

Aguilera RV, Rupp DE, Williams CA, Ganapathi J (2007) Putting the S back in corporate social responsibility: a multilevel theory of social change in organizations. Acad Manage Rev 32:836-863. https:// doi.org/10.5465/AMR.2007.25275678

Akerlof GA, Kranton RE (2005) Identity and the economics of organizations. J Econ Perspect 19:9-32

Altenburger M (2020) The effect of corporate giving and participation on employee performance and performance overstatement. Working paper

Andersson O, Holm HJ, Tyran J-R, Wengström E (2016) Deciding for others reduces loss aversion. Manage Sci 62:29-36. https://doi.org/10.1287/mnsc.2014.2085

Andreoni J (1990) Impure altruism and donations to public goods: a theory of warm-glow giving. Econ J 100:464-477. https://doi.org/10.2307/2234133

Andreoni J, Miller J (2002) Giving according to GARP: an experimental test of the consistency of preferences for altruism. Econometrica 70:737-753

Ariely D, Kamenica E, Prelec D (2008) Man's search for meaning: the case of Legos. J Econ Behav Organ 67:671-677. https://doi.org/10.1016/j.jebo.2008.01.004

Backes-Gellner U, Pull K (2013) Tournament compensation systems, employee heterogeneity, and firm performance. Hum Resour Manage 52:375-398. https://doi.org/10.1002/hrm.21535

Balakrishnan R, Sprinkle GB, Williamson MG (2011) Contracting benefits of corporate giving: an experimental investigation. Account Rev 86:1887-1907. https://doi.org/10.2308/accr-10127

Bekkers R, Ottoni-Wilhelm M (2016) Principle of care and giving to help people in need. Eur J Pers 30:240-257. https://doi.org/10.1002/per.2057

Belot M, Duch R, Miller L (2015) A comprehensive comparison of students and non-students in classic experimental games. J Econ Behav Organ 113:26-33. https://doi.org/10.1016/j.jebo.2015.02.007

Benabou R, Tirole J (2010) Individual and corporate social responsibility. Economica 77:1-19. https:// doi.org/10.1111/j.1468-0335.2009.00843.x

Berg N, Gigerenzer G (2010) As-if-behavioral economics: neoclassical economics in disguise? Hist Econ Ideas 18:133-165

Besley T, Ghatak M (2005) Competition and incentives with motivated agents. Am Econ Rev 95:616-636

Bicchieri C (2006) The grammar of society: the nature and dynamics of social norms. Cambridge University Press, Cambridge

Bicchieri C (2008) The fragility of fairness: An experimental investigation on the conditional status of pro-social norms. Philos Issues 18:229-248

Blais A-R, Weber EU (2006) A domain-specific risk-taking (DOSPERT) scale for adult populations. Judgm Decis Mak 1:33-47

Bolino M, Long D, Turnley W (2016) Impression management in organizations: critical questions, answers, and areas for future research. Annu Rev Organ Psych Organ Behav 3:377-406. https://doi. org/10.1146/annurev-orgpsych-041015-062337

Bolton P, Mehran H, Shapiro J (2015a) Executive compensation and risk taking. Rev Fin 19:2139-2181. https://doi.org/10.1093/rof/rfu049

Bolton GE, Ockenfels A, Stauf J (2015b) Social responsibility promotes conservative risk behavior. Eur Econ Rev 74:109-127. https://doi.org/10.1016/j.euroecorev.2014.10.002

Bowles S, Polanía-Reyes S (2012) Economic incentives and social preferences: substitutes or complements? J Econ Lit 50:368-425

Brañas-Garza P (2006) Poverty in dictator games: awakening solidarity. J Econ Behav Organ 60:306320. https://doi.org/10.1016/j.jebo.2004.10.005 
Brink AG, Hobson JL, Stevens DE (2017) The effect of high power financial incentives on excessive risktaking behavior: an experimental examination. J Manage Account Res 29:13-29. https://doi.org/10. 2308/jmar-51533

Brown WO, Helland E, Smith JK (2006) Corporate philanthropic practices. J Corp Finan 12:855-877. https://doi.org/10.1016/j.jcorpfin.2006.02.001

Brown AL, Meer J, Williams JF (2017) Social distance and quality ratings in charity choice. J Behav Exp Econ 66:9-15. https://doi.org/10.1016/j.socec.2016.04.006

Burbano VC (2016) Social responsibility messages and worker wage requirements: field experimental evidence from online labor marketplaces. Organ Sci 27:1010-1028. https://doi.org/10.1287/orsc. 2016.1066

Cappelen AW, Nygaard K, Sørensen EØ, Tungodden B (2015) Social preferences in the lab: a comparison of students and a representative population. Scand J of Econ 117:1306-1326. https://doi.org/ $10.1111 /$ sjoe. 12114

Carpenter J, Gong E (2016) Motivating agents: how much does the mission matter? J Law Econ 34:211236. https://doi.org/10.1086/682345

Cassar L, Meier S (2017) Intentions for doing good matter for doing well: the (negative) signaling value of prosocial incentives. NBER working paper no. 24109. https://doi.org/10.3386/w24109

Charness G, Gneezy U (2008) What's in a name?: anonymity and social distance in dictator and ultimatum games. J Econ Behav Organ 68:29-35. https://doi.org/10.1016/j.jebo.2008.03.001

Charness G, Jackson MO (2009) The role of responsibility in strategic risk-taking. J Econ Behav Organ 69:241-247. https://doi.org/10.1016/j.jebo.2008.10.006

Charness G, Gneezy U, Imas A (2013) Experimental methods: eliciting risk preferences. J Econ Behav Organ 87:43-51. https://doi.org/10.1016/j.jebo.2012.12.023

Charness G, Cobo-Reyes R, Sánchez Á (2016) The effect of charitable giving on workers?: performance: experimental evidence. J Econ Behav Organ 131:61-74. https://doi.org/10.1016/j.jebo.2016.08.009

Chen Y (2015) Career concerns and excessive risk taking. J Econ Manage Strategy 24:110-130. https:// doi.org/10.1111/jems.12085

Chen JC, Patten DM, Roberts RW (2008) Corporate charitable contributions: a corporate social performance or legitimacy strategy? J Bus Ethics 82:131-144. https://doi.org/10.1007/ s10551-007-9567-1

Christ MH, Vance TW (2018) Cascading controls: the effects of managers' incentives on subordinate effort to help or harm. Acc Organ Soc 65:20-32. https://doi.org/10.1016/j.aos.2017.10.003

Church BK, Jiang W, Kuang X, Vitalis A (2019) A dollar for a tree or a tree for a dollar? The behavioral effects of measurement basis on managers' CSR investment decision. Account Rev 94:117-137. https://doi.org/10.2308/accr-52332

Clarkson MBE (1995) A stakeholder framework for analyzing and evaluating corporate social performance. Acad Manage Rev 20:92-117. https://doi.org/10.2307/258888

Cohn A, Fehr E, Maréchal MA (2017) Do professional norms in the banking industry favor risk-taking? Rev Fin Stud 30:3801-3823. https://doi.org/10.1093/rfs/hhx003

Collier J, Esteban R (2007) Corporate social responsibility and employee commitment. Bus Ethics Eur Rev 16:19-33

Conyon MJ, Fernandes N, Ferreira MA, Matos P, Murphy KJ (2011) The executive compensation controversy: a transatlantic analysis. http://digitalcommons.ilr.cornell.edu/ics/5

Cooper DJ, Kagel JH (2016) Other-regarding preferences: a selective survey of experimental results. In: Kagel JH, Roth AE (eds) The handbook of experimental economics, vol 2. Princeton University Press, Princeton, NJ, pp 217-289

Corbett J, Webster J, Jenkin T (2018) Unmasking corporate sustainability at the project level: exploring the influence of institutional logics and individual agency. J Bus Ethics 147:261-286. https://doi. org/10.1007/s10551-015-2945-1

Costa PT, McCrae RR (1992) Revised NEO personality inventory (NEO PI-R) and NEO five-factor inventory (NEO-FFI). Psychological Assessment Resources Inc, Odessa, FL

Costas J, Kärreman D (2013) Conscience as control-managing employees through CSR. Organization 20:394-415. https://doi.org/10.1177/1350508413478584

Dittmann I, Maug E, Zhang D (2011) Restricting CEO pay. J Corp Fin 17:1200-1220. https://doi.org/10. 1016/j.jcorpfin.2011.04.007

Douthit J, Martin P, McAllister M (2019) Charitable contribution matching and effort-elicitation. Working paper

Druckman JN, McDermott R (2008) Emotion and the framing of risky choice. Polit Behav 30:297-321 
Du S, Vieira ET (2012) Striving for legitimacy through corporate social responsibility: insights from oil companies. J Bus Ethics 110:413-427. https://doi.org/10.1007/s10551-012-1490-4

Durden C (2008) Towards a socially responsible management control system. Account Audit Account J 21:671-694. https://doi.org/10.1108/09513570810872969

Eckel CC, Grossman PJ (1996) Altruism in anonymous dictator games. Games Econ Behav 16:181-191. https://doi.org/10.1006/game.1996.0081

Eriksen KW, Kvaløy O (2017) No guts, no glory: an experiment on excessive risk-taking. Rev Fin 21:1327-1351. https://doi.org/10.1093/rof/rfw016

Federal Reserve Press Release (2009) Federal reserve issues proposed guidance on incentive compensation

Fehr E, Schmidt KM (1999) A theory of fairness, competition, and cooperation. Q J Econ 114:817-868

Fehrler S, Kosfeld M (2014) Pro-social missions and worker motivation: an experimental study. J Econ Behav Organ 100:99-110. https://doi.org/10.1016/j.jebo.2014.01.010

Fehrler S, Przepiorka W (2016) Choosing a partner for social exchange: charitable giving as a signal of trustworthiness. J Econ Behav Organ 129:157-171. https://doi.org/10.1016/j.jebo.2016.06.006

Filatotchev I, Nakajima C (2014) Corporate governance, responsible managerial behavior, and corporate social responsibility: organizational efficiency versus organizational legitimacy? Acad Manage Perspect 28:289-306. https://doi.org/10.5465/amp.2014.0014

Fischbacher U (2007) z-Tree: Zurich toolbox for ready-made economic experiments. Exp Econ 10:171-178

Gneezy U, Potters J (1997) An experiment on risk taking and evaluation periods. Q J Econ 112:631-645

Gond J-P, Grubnic S, Herzig C, Moon J (2012) Configuring management control systems: theorizing the integration of strategy and sustainability. Manage Account Res 23:205-223. https://doi.org/10. 1016/j.mar.2012.06.003

Gond J-P, El Akremi A, Swaen V, Babu N (2017) The psychological microfoundations of corporate social responsibility: a person-centric systematic review. J Org Behav 38:225-246. https://doi.org/ 10.1002/job. 2170

Grant AM (2008) The significance of task significance: job performance effects, relational mechanisms, and boundary conditions. J Appl Psychol 93:108-124. https://doi.org/10.1037/0021-9010.93.1.108

Groom B (2018) How giving back can pay back. Fin Times

Haisley EC, Weber RA (2010) Self-serving interpretations of ambiguity in other-regarding behavior. Games Econ Behav 68:614-625. https://doi.org/10.1016/j.geb.2009.08.002

Hales J (2007) Directional preferences, information processing, and investors' forecasts of earnings. J Account Res 45:607-628. https://doi.org/10.1111/j.1475-679X.2007.00247.x

Hales J, Matsumura EM, Moser DV, Payne R (2016) Becoming sustainable: a rational decision based on sound information and effective processes? J Manage Account Res 28:13-28. https://doi.org/10. 2308/jmar-51394

Hall AT, Bowen MG, Ferris GR, Royle MT, Fitzgibbons DE (2007) The accountability lens: a new way to view management issues. Bus Horiz 50:405-413. https://doi.org/10.1016/j.bushor.2007.04.005

Harjoto M, Laksmana I (2018) The impact of corporate social responsibility on risk taking and firm value. J Bus Ethics 151:353-373. https://doi.org/10.1007/s10551-016-3202-y

Heinicke A, Guenther TW, Widener SK (2016) An examination of the relationship between the extent of a flexible culture and the levers of control system: the key role of beliefs control. Manage Account Res 33:25-41. https://doi.org/10.1016/j.mar.2016.03.005

Hobson JL, Sommerfeldt R, Wang LW (2019) Cheating for the cause: the effects of performance-based pay on socially-oriented misreporting. SSRN J. https://doi.org/10.2139/ssrn.3226982

Holt CA, Laury SK (2002) Risk aversion and incentive effects. Am Econ Rev 92:1644-1655

Huang XB, Watson L (2015) Corporate social responsibility research in accounting. J Account Lit 34:116. https://doi.org/10.1016/j.acclit.2015.03.001

Imas A (2014) Working for the "warm glow": on the benefits and limits of prosocial incentives. J Public Econ 114:14-18. https://doi.org/10.1016/j.jpubeco.2013.11.006

Jensen MC, Meckling WH (1976) Theory of the firm: managerial behavior, agency costs and ownership structure. J Fin Econ 3:305-360. https://doi.org/10.1016/0304-405X(76)90026-X

Jokivuolle E, Keppo J, Yuan X (2019) Bonus caps, deferrals and bankers' risk-taking. Bank of Finland Research Discussion Paper. https://doi.org/10.2139/ssrn.2346602

Joshi S, Li Y (2016) What is corporate sustainability and how do firms practice it? A management accounting research perspective. J Manage Account Res 28:1-11. https://doi.org/10.2308/ jmar-10496 
Kajackaite A, Sliwka D (2017) Social responsibility and incentives in the lab: why do agents exert more effort when principals donate? J Econ Behav Organ 142:482-493. https://doi.org/10.1016/j.jebo. 2017.08.013

Kennedy FA, Widener SK (2019) Socialization mechanisms and goal congruence. Acc Organ Soc 76:3249. https://doi.org/10.1016/j.aos.2019.01.004

Kirkpatrick G (2009) The corporate governance lessons from the financial crisis. OECD J Fin Market Trends 2009:61-87

Koppel H, Regner T (2014) Corporate social responsibility in the work place. Exp Econ 17:347-370. https://doi.org/10.1007/s10683-013-9372-X

Kreilkamp N, Matanovic S, Schmidt M, Wöhrmann A (2019) How incentive system design affects risktaking: a literature review. SSRN J. https://doi.org/10.2139/ssrn.3373121

Kreilkamp N, Matanovic S, Sommer F, Wöhrmann A (2020) The effect of compensation caps on risktaking. J Manage Account Res. https://doi.org/10.2308/JMAR-18-053

Kunda Z (1990) The case for motivated reasoning. Psychol Bull 108:480-498. https://doi.org/10.1037/ 0033-2909.108.3.480

Latané B, Nida S (1981) Ten years of research on group size and helping. Psychol Bull 89:308-324

Lazear EP (2018) Compensation and incentives in the workplace. J Econ Perspect 32:195-214. https:// doi.org/10.1257/jep.32.3.195

Lefebvre M, Vieider FM (2013) Reining in excessive risk-taking by executives: the effect of accountability. Theory Decis 75:497-517. https://doi.org/10.1007/s11238-012-9335-2

Lerner JS, Tetlock PE (1999) Accounting for the effects of accountability. Psychol Bull 125:255-275. https://doi.org/10.1037/0033-2909.125.2.255

List JA (2007) On the interpretation of giving in dictator games. J Polit Econ 115:482-493. https://doi. org/10.1086/519249

Lönnqvist J-E, Verkasalo M, Walkowitz G, Wichardt PC (2015) Measuring individual risk attitudes in the lab: task or ask? An empirical comparison. J Econ Behav Organ 119:254-266. https://doi.org/10. 1016/j.jebo.2015.08.003

Lueg R, Radlach R (2016) Managing sustainable development with management control systems: a literature review. Eur Manage J 34:158-171. https://doi.org/10.1016/j.emj.2015.11.005

Luft J, Shields MD (2009) Psychology models of management accounting. Found Trends Account 4:199-345. https://doi.org/10.1561/1400000015

March JG, Shapira Z (1992) Variable risk preferences and the focus of attention. Psychol Rev 99:172183. https://doi.org/10.1037/0033-295X.99.1.172

Marginson D (2009) Value systems as a mechanism for organizational change. J Acc Organ Change 5:7-34. https://doi.org/10.1108/18325910910932197

Masulis RW, Reza SW (2015) Agency problems of corporate philanthropy. Rev Fin Stud 28:592-636

McShane L, Cunningham P (2012) To thine own self be true? Employees' judgments of the authenticity of their organization's corporate social responsibility program. J Bus Ethics 108:81-100. https://doi.org/10.1007/s10551-011-1064-x

McWilliams A, Siegel D (2001) Corporate social responsibility: a theory of the firm perspective. Acad Manage Rev 26:117-127. https://doi.org/10.2307/259398

Mellers BA (2000) Choice and the relative pleasure of consequences. Psychol Bull 126:910-924. https://doi.org/10.1037/0033-2909.126.6.910

Merchant KA, Otley DT (2006) A review of the literature on control and accountability. In: Chapman CS, Hopwood AG, Shields MD (eds) Handbooks of management accounting research, vol 2. Elsevier, Amsterdam, pp 785-802

Merchant KA, van der Stede WA (2017) Management control systems: Performance measurement, evaluation and incentives, 4th edn. Financial Times Prentice Hall, Harlow

Microsoft (2020) Maximize your Microsoft match. https:/query.prod.cms.rt.microsoft.com/cms/api/ am/binary/RE1Fw3y. Accessed 7 June 2021

Montinari N, Rancan M (2018) Risk taking on behalf of others: the role of social distance. J Risk Uncertain 57:81-109. https://doi.org/10.1007/s11166-018-9286-2

Moser DV, Martin PR (2012) A broader perspective on corporate social responsibility research in accounting. Account Rev 87:797-806. https://doi.org/10.2308/accr-10257

Murphy KJ (2013) Executive compensation: where we are, and how we got there. In: Constantinides GM, Harris M, Stulz RM (eds) Handbook of the economics of finance, vol 2. Elsevier, Boston, Heidelberg, pp 211-356

Nelson B (2012) 1501 ways to reward employees. Workman Pub, New York 
Nelson B (2018) 1,001 ways to engage employees: help people do better what they do best. Career Press, Newburyport

Nicholson N, Soane E, Fenton-O’Creevy M, Willman P (2005) Personality and domain-specific risk taking. J Risk Res 8:157-176. https://doi.org/10.1080/1366987032000123856

Noreen E (1988) The economics of ethics: a new perspective on agency theory. Acc Organ Soc 13:359-369. https://doi.org/10.1016/0361-3682(88)90010-4

Oikonomou I, Brooks C, Pavelin S (2012) The impact of corporate social performance on financial risk and utility: a longitudinal analysis. Fin Manage 41:483-515

Pahlke J, Strasser S, Vieider FM (2015) Responsibility effects in decision making under risk. J Risk Uncertain 51:125-146. https://doi.org/10.1007/s11166-015-9223-6

Peterson DK (2004) The relationship between perceptions of corporate citizenship and organizational commitment. Bus Soc 43:296-319. https://doi.org/10.1177/0007650304268065

Pham MT (2007) Emotion and rationality: a critical review and interpretation of empirical evidence. Rev Gen Psychol 11:155-178. https://doi.org/10.1037/1089-2680.11.2.155

Pikulina E, Renneboog L, Tobler PN (2017) Overconfidence and investment: an experimental approach. J Corp Finan 43:175-192. https://doi.org/10.1016/j.jcorpfin.2017.01.002

Pirson M, Turnbull S (2016) Decentralized governance structures are able to handle CSR-induced complexity better. Bus Soc 57:929-961. https://doi.org/10.1177/0007650316634039

Pollmann MM, Potters J, Trautmann ST (2014) Risk taking by agents: the role of ex-ante and ex-post accountability. Econ Lett 123:387-390. https://doi.org/10.1016/j.econlet.2014.04.004

Pratt MG, Ashforth BE (2003) Fostering meaningfulness in working and at work. In: Cameron KS, Dutton JE, Quinn RE (eds) Positive organizational scholarship: foundations of a new discipline. Berrett-Koehler, San Francisco, CA, pp 309-327

Prendergast C (2007) The motivation and bias of bureaucrats. Am Econ Rev 97:180-196

Preston C (2016) The 20 most generous companies of the Fortune 500. http://fortune.com/2016/06/ 22/fortune-500-most-charitable-companies/. Accessed 21 March 2017

Rebitzer JB, Taylor LJ (2011) Extrinsic rewards and intrinsic motives: standard and behavioral approaches to agency and labor markets. In: Ashenfelter O, Card D (eds) Handbook of labor economics, vol 4. Elsevier, Amsterdam, pp 701-772

Resh WG, Marvel JD, Wen B (2018) The persistence of prosocial work effort as a function of mission match. Public Admin Rev 78:116-125. https://doi.org/10.1111/puar.12882

Rotemberg JJ (2006) Altruism, reciprocity and cooperation in the workplace. In: Kolm S-C, Ythier JM (eds) Handbook of the economics of giving, altruism and reciprocity: applications, vol 2. Elsevier, Amsterdam, The Netherlands, pp 1371-1407

Rushton JP, Chrisjohn RD, Fekken GC (1981) The altruistic personality and the self-report altruism scale. Pers Individ Differ 2:293-302. https://doi.org/10.1016/0191-8869(81)90084-2

Salazar J, Husted B, Biehl M (2012) Thoughts on the evaluation of corporate social performance through projects. J Bus Ethics 105:175-186. https://doi.org/10.1007/s10551-011-0957-z

Sanders WG, Hambrick DC (2007) Swinging for the fences: the effects of CEO stock options on company risk taking and performance. Acad Manage J 50:1055-1078. https://doi.org/10.2307/ 20159913

Schedlinsky I, Sommer F, Wöhrmann A (2016) Risk-taking in tournaments: an experimental analysis. J Bus Econ 86:837-866. https://doi.org/10.1007/s11573-016-0813-9

Schedlinsky I, Sommer F, Wöhrmann A (2018) Influencing risk taking in competitive environments: an experimental analysis. J Risk Fin 19:396-412. https://doi.org/10.1108/JRF-11-2017-0193

Schwartz MS (2013) Developing and sustaining an ethical corporate culture: the core elements. Bus Horiz 56:39-50. https://doi.org/10.1016/j.bushor.2012.09.002

Simonson I (1989) Choice based on reasons: the case of attraction and compromise effects. J Consum Res 16:158-174

Simonson I, Nye P (1992) The effect of accountability on susceptibility to decision errors. Organ Behav Hum Decis Process 51:416-446. https://doi.org/10.1016/0749-5978(92)90020-8

Sitkin SB, Pablo AL (1992) Reconceptualizing the determinants of risk behavior. Acad Manage Rev 17:9-38. https://doi.org/10.2307/258646

Slovic P, Peters E (2006) Risk perception and affect. Curr Dir Psychol Sci 15:322-325. https://doi. org/10.1111/j.1467-8721.2006.00461.x

Slovic P, Finucane ML, Peters E, MacGregor DG (2007) The affect heuristic. Eur J Oper Res 177:1333-1352. https://doi.org/10.1016/j.ejor.2005.04.006 
Small DA (2011) Sympathy biases and sympathy appeals: reducing social distance to boost charitable contributions. In: Oppenheimer DM, Olivola CY (eds) The science of giving: experimental approaches to the study of charity. Psychology Press, New York, NY, pp 149-160

Small DA, Simonsohn U (2008) Friends of victims: personal experience and prosocial behavior. J Consum Res 35:532-542. https://doi.org/10.1086/527268

Smith J (2016) The motivational effects of mission matching: a lab-experimental test of a moderated mediation model. Public Admin Rev 76:626-637. https://doi.org/10.1111/puar.12514

Sprinkle GB, Maines LA (2010) The benefits and costs of corporate social responsibility. Bus Horiz 53:445-453. https://doi.org/10.1016/j.bushor.2010.05.006

Sprinkle GB, Williamson MG, Upton DR (2008) The effort and risk-taking effects of budget-based contracts. Acc Organ Soc 33:436-452. https://doi.org/10.1016/j.aos.2007.11.001

Swanson DL (1995) Addressing a theoretical problem by reorienting the corporate social performance model. Acad Manage Rev 20:43-64. https://doi.org/10.5465/amr.1995.9503271990

Swanson DL (1999) Toward an integrative theory of business and society: a research strategy for corporate social performance. Acad Manage Rev 24:506-521. https://doi.org/10.5465/amr.1999. 2202134

Till RE, Yount MB (2019) Governance and incentives: is it really all about the money? J Bus Ethics 159:605-618. https://doi.org/10.1007/s10551-018-3778-5

Tonin M, Vlassopoulos M (2010) Disentangling the sources of pro-socially motivated effort: a field experiment. J Public Econ 94:1086-1092. https://doi.org/10.1016/j.jpubeco.2010.08.011

Tonin M, Vlassopoulos M (2013) Experimental evidence of self-image concerns as motivation for giving. J Econ Behav Organ 90:19-27. https://doi.org/10.1016/j.jebo.2013.03.011

Tonin M, Vlassopoulos M (2015) Corporate philanthropy and productivity: evidence from an online real effort experiment. Manage Sci 61:1795-1811. https://doi.org/10.1287/mnsc.2014.1985

Trautmann ST, Vieider FM (2012) Social influences on risk attitudes: applications in economics. In: Roeser S, Hillerbrand R, Sandin P, Peterson M (eds) Handbook of risk theory. Springer, Netherlands, Dordrecht, The Netherlands, pp 575-600

Valentine S, Fleischman G (2008) Ethics programs, perceived corporate social responsibility and job satisfaction. J Bus Ethics 77:159-172. https://doi.org/10.1007/s10551-006-9306-Z

Weigold MF, Schlenker BR (1991) Accountability and risk taking. Pers Soc Psychol Bull 17:25-29. https://doi.org/10.1177/0146167291171004

Wolfgramm R, Flynn-Coleman S, Conroy D (2015) Dynamic interactions of agency in leadership (DIAL): an integrative framework for analysing agency in sustainability leadership. J Bus Ethics 126:649-662. https://doi.org/10.1007/s10551-013-1977-7

Publisher's Note Springer Nature remains neutral with regard to jurisdictional claims in published maps and institutional affiliations. 